University of Wollongong

Research Online

Faculty of Business - Papers (Archive)

Faculty of Business and Law

2020

Does practice make micro-entrepreneurs perfect? An investigation of expertise acquisition using effectuation and causation

Nadeera Ranabahu

University of Canterbury, nurm263@uowmail.edu.au

Mary Barrett

University of Wollongong, mbarrett@uow.edu.au

Follow this and additional works at: https://ro.uow.edu.au/buspapers

Part of the Business Commons

Research Online is the open access institutional repository for the University of Wollongong. For further information contact the UOW Library: research-pubs@uow.edu.au 


\title{
Does practice make micro-entrepreneurs perfect? An investigation of expertise acquisition using effectuation and causation
}

\author{
Abstract \\ This paper reports on a study testing whether and how the use of effectuation and causation logics \\ influences deliberate practice in businesses started by microfinance borrowers ("micro-entrepreneurs") in \\ Sri Lanka. Using mixed methods, we surveyed clients of a large Sri Lankan microfinance institution and \\ deepened findings from the survey through 24 interviews. In this way, we identified specific patterns of \\ relationships between principles of the two logics and five elements of deliberate practice identified in the \\ expertise literature from cognitive science. We found that both effectual and causal logics (but not \\ effectuation alone) facilitate deliberate practice, an important result since deliberate practice could be \\ expected to help micro-entrepreneurs gain business and entrepreneurial expertise. We also found \\ interesting patterns in the links among effectuation and causation and specific elements of deliberate \\ practice. In particular, one effectuation principle-acknowledging and leveraging the unexpected-impacted \\ all five elements of deliberate practice, suggesting that learning to manage uncertainty is a central task- \\ perhaps the central task-in becoming an entrepreneur. By contrast, causation influenced elements of \\ deliberate practice linked to "venture-building" or "entrepreneuring," and not the more personal elements \\ linked to seeing oneself as an entrepreneur. As expected from the literature on expertise, deliberate \\ practice was more likely to occur in earlier stages of venturing by younger, less-experienced \\ entrepreneurs. Findings not only offer avenues for future research into deliberate practice in \\ entrepreneurship but also suggest new ways for microfinance institutions to help their clients move \\ toward entrepreneurial expertise.

\section{Disciplines \\ Business}

\section{Publication Details} \\ Ranabahu, N. \& Barrett, M. (2020). Does practice make micro-entrepreneurs perfect? An investigation of \\ expertise acquisition using effectuation and causation. Small Business Economics: an international \\ journal, 54 883-905.
}




\title{
Does practice make micro-entrepreneurs perfect? An investigation of expertise acquisition using effectuation and causation
}

\begin{abstract}
The paper reports on a study testing whether effectuation (means-driven thinking) and causation (predictive thinking) influence the use of deliberate practice during business start-up by microfinance borrowers ('micro-entrepreneurs') running low-tech businesses in Sri Lanka. We surveyed clients of a large Sri Lankan microfinance institution and analysed 24 interviews with a separate group to see whether links existed, and if so how they played out in everyday business practice.

Results showed that both effectual and causal logics (not effectuation alone) facilitate deliberate practice, which in turn helps micro-entrepreneurs gain business expertise. We also found conceptual links between effectuation and causation and some elements of deliberate practice, and specific effectuation and causation actions lay a foundation for repetitive practice. Importantly, causation logic and certain effectuation principles influenced some rather than all five elements of deliberate practice. One effectuation principle, 'acknowledging the unexpected', impacted all five elements of deliberate practice, suggesting that learning to manage uncertainty is crucial task in becoming an entrepreneur. By contrast, causation influenced elements of deliberate practice linked to "venturebuilding" or "entrepreneuring", but not elements linked to managing oneself as an entrepreneur. Micro-entrepreneurs with younger ( $\leq 5$ years), lower asset-value businesses $(\leq 150,000 \mathrm{SLR})$ were significantly more engaged with entrepreneurial learning than micro-entrepreneurs running older, higher asset-value businesses.

Our findings suggest new ways that microfinance institutions could help their clients become expert entrepreneurs. Future researchers could test whether our findings hold in other entrepreneurial populations, and whether there are patterns in how micro-entrepreneurs (and others) manage uncertainty.
\end{abstract}

Keywords: Effectuation, causation, deliberate practice, micro-entrepreneurs, microfinance, Sri Lanka

JEL Classifications: M13, L26

\section{Introduction}

This paper reports on a study of how clients of a Sri Lankan microfinance institute (MFI) use effectuation thinking, causation thinking, and deliberate practice. Effectuation thinking refers to 
entrepreneurs' use of their available means in business start-up while causation thinking highlights a contrasting approach: sourcing specific means to achieve pre-defined goals (Sarasvathy 2001). Both ways of thinking reflect a process perspective on entrepreneurship, that is, they focus on what entrepreneurs do, not who entrepreneurs are (trait perspectives) (Aldrich \& Martinez 2001; Shane 2012; Shane \& Venkataraman 2000). While effectuation theory was initially developed more than 15 years ago, it has been incorporated only rather slowly into the wider entrepreneurial literature (Arend et al. 2015; Ghorbel \& Boujelbène 2013; Perry et al. 2012). There have been ongoing calls for further research to clarify the concept of effectuation, theorize its conceptual boundaries, and link it with other concepts, models, and theories to advance its use within the entrepreneurial domain (Arend et al. 2015, 2016; Perry et al. 2012). Our study addresses this call by investigating whether there are links between micro-entrepreneurs' use of effectuation and/or causation, and their use of deliberate practice to acquire business and entrepreneurial expertise.

Thus the major aim of this study is to explore whether and how using effectuation and causation logics facilitates deliberate practice among micro-entrepreneurs (see section 2.5 for why we use this term). Specifically, we address three questions:

1. to what extent do micro-entrepreneurs use effectuation (or causation) logic during business start-up?

2. to what extent does using effectual and causal logics facilitate micro-entrepreneurs' use of deliberate business practice?

3. how do all three concepts - effectuation, causation and deliberate practice - manifest themselves 'on the ground' in this novel context, especially in terms of changes to microentrepreneurs' businesses?

Answering these questions would contribute theoretically to our understanding of entrepreneurship and add to empirical evidence about effectuation, causation, and deliberate practice by examining them in a novel setting: women business owners in a developing country who have received microfinance loans. We also consider how microfinance lending institutions could improve clients' entrepreneurial skills by improving their opportunities for deliberate practice.

The next section discusses the theoretical foundations of the study.

\section{Theoretical foundation}

This study is grounded in two main theoretical domains: a) effectuation and causation in entrepreneurship theory, and b) deliberate practice in the cognitive sciences. 


\subsection{Effectuation and causation thinking}

Effectuation refers to the ways entrepreneurial thinking is basically 'means-driven' rather than 'goals-driven' or causation-based (Sarasvathy 2001; 2008). Effectual entrepreneurs use their immediate resources, knowledge, skills, and even their personal identity as means for starting a business. In doing so they take actions based on their assessment of what they can afford to lose, form partnerships with individuals close to them, perceive contingencies as opportunities rather than seeking to avoid contingencies, and rely on their own experience (Chandler et al. 2011; Dew et al. 2009; Fisher 2012; Sarasvathy 2001; 2008). In contrast, when goals-driven, or 'causal' entrepreneurs start a business, they begin with specific goals and select the required means to achieve these goals. They analyse the market, use control processes to avoid contingencies, and rely on predictions and forecasts (Chandler et al. 2011; Fisher 2012; Sarasvathy 2001; 2008). Thus effectuation rationality is the inverse of causal rationality (Read \& Sarasvathy 2005). Table 1 illustrates the key differences between the two approaches to entrepreneurship.

Table 1: Comparing effectuation and causation

\begin{tabular}{|c|c|c|}
\hline & Effectuation & Causation \\
\hline Problem space & Markets are highly uncertain. & $\begin{array}{l}\text { Markets are reasonably certain and } \\
\text { predictable. }\end{array}$ \\
\hline Overall logic & $\begin{array}{l}\text { Means are given and entrepreneurs } \\
\text { focus on creating possible effects using } \\
\text { the available means. }\end{array}$ & $\begin{array}{l}\text { Effects are given and entrepreneurs select } \\
\text { between means to achieve the pre- } \\
\text { defined effects. }\end{array}$ \\
\hline \multirow[t]{5}{*}{$\begin{array}{l}\text { Fundamental } \\
\text { principles }\end{array}$} & $\begin{array}{l}\text { Use of means-driven approaches: } \\
\text { Answers to questions of identity (who I } \\
a m \text { ), knowledge (what I know), and } \\
\text { network (whom I know) are the basis of } \\
\text { starting a business. Following Chandler } \\
\text { (2011), these sub-constructs are } \\
\text { operationalized as 'experimentation'. }\end{array}$ & $\begin{array}{l}\text { Use of goals-driven approaches: } \\
\text { Means are sourced to achieve the pre- } \\
\text { defined goals. }\end{array}$ \\
\hline & Actions are based on affordable loss: & Actions are based on expected returns: \\
\hline & $\begin{array}{l}\text { The amount one is willing to put at risk } \\
\text { is considered before making decisions. }\end{array}$ & $\begin{array}{l}\text { Returns and risks are calculated before } \\
\text { making decisions. }\end{array}$ \\
\hline & $\underline{\text { Use of alliances/pre-agreements: }}$ & Use of competitive market analysis: \\
\hline & $\begin{array}{l}\text { Partnerships and pre-agreements are } \\
\text { formed to reduce uncertainty. }\end{array}$ & $\begin{array}{l}\text { Market conditions and competition are } \\
\text { analysed as the basis for decision-making. }\end{array}$ \\
\hline
\end{tabular}


Acknowledging the unexpected:

Unexpected events are considered as

opportunities, hence, entrepreneurs are

adaptive and flexible.

Use of non-predictive control:

Entrepreneurs use their own experience

to make decisions.
Overcoming the unexpected:

Unexpected events are considered

obstacles, hence control decisions are

used to avoid them.

Use of predictive control:

Entrepreneurs rely on forecasts and projections to make business decisions.

Source: Adapted from Brettel et al. (2012), Chandler et al. (2011), Dew et al. (2009), Fisher (2012), Sarasvathy $(2001 ; 2008)$, Sarasvathy \& Dew (2005)

Read and Sarasvathy (2005) argue that successful firms are more likely to begin through effectual thinking but to grow using causal actions. Confirming this, Daniel et al. (2015) in a study of on-line home businesses, Yusuf and Sloan (2015) who studied not-for-profits, and Andersson (2011), Chetty et al. (2015), and Evald and Senderovitz (2013) who focussed on international businesses, all found that effectuation thinking is prominent during business start-up. Similarly, Berends et al. (2013) found that small manufacturing firms use effectuation in the early stages of a business but causation in the development phase. In contrast, however, Evald and Senderovitz (2013) and Gabrielsson M and Gabrielsson P (2013) found that entrepreneurs use effectual logic even at the development stage of the business, while Maine et al. (2015), Nummela et al. (2014), and Reymen et al. (2015) found that 'hybrid' thinking-a combination of effectual and causal decisions-is used in expanding businesses.

\subsection{Deliberate practice}

Deliberate practice refers to the process of achieving expertise through self-regulated, effortful, and repetitive activities (Ericsson et al. 1993). Typically, an individual needs to engage in domain-related activities on a long-term basis to attain an expert level of performance (Ericsson 2006; 2008). There are several conditions that need to be fulfilled for a task to be seen as deliberate practice. It must: (a) have a well-defined performance improvement goal, (b) be undertaken with the motive to improve, (c) allow feedback to improve the process, and (d) allow ample opportunities for repetition and gradual refinement of performance (Ericsson 2006; 2008). These aspects of an activity contribute to the expansion of domain-specific knowledge, skills, and cognitive resources such as memory, perception, intuition, and meta-cognition (Baron \& Henry 2010).

Deliberate practice is used - and has been studied - in fields such as music (Ericsson et al. 1993), sports (Hodges et al. 2006), chess (Charness et al. 2005), and artistic performance (Noice H \& Noice T 2006). However, in contrast to the well-defined tasks that characterize gaining expertise in music, 
ballet, and sports, entrepreneurial activities are typically not clear-cut, due to the idiosyncratic nature of business tasks and sub-tasks (Keith et al. 2016; Unger et al. 2009). So it is less clear how entrepreneurial activities lend themselves to deliberate practice. The same is true of other professional domains such as insurance (Sonnentag \& Kleine 2000), software design (Sonnentag et al. 2006), and medicine and surgery (Norman et al. 2006). So, while specific entrepreneurial activities that can be used as sources of deliberate practice are difficult to discern, activities such as financial management, stakeholder negotiations, and time and people management can be conducted repetitively to improve performance (Baron \& Henry 2010; Read \& Sarasvathy 2005; Unger et al. 2009). Another difference is that in classical domains of practice there is a teacher or an instructor who structures activities and provides feedback, whereas business tasks are complex and the learning process is typically self-regulated and informal (Keith et al. 2016).

Studies of deliberate practice among entrepreneurs are few, and the literature mostly focuses on the psychological and cognitive benefits of deliberate practice to the entrepreneur rather than the changes it might make to how the business is run. For example, Unger et al. (2009) developed a cognitive model of learning using South African small business owners. Keith et al. (2016) replicated Unger et al.'s (2009) study among German small business owners using a longitudinal design and focusing on the moderating effect of environmental dynamism on deliberate practice. They found that the benefits of practice to entrepreneurs are higher in dynamic business environments. Baron and Henry (2010) studied how entrepreneurs use repetitive practice to enhance cognitive resources such as memory, perception, intuition, and meta-cognition. In the present study, rather than considering the benefits of practice to entrepreneurs, we consider how effectual (and indeed causal) decision-making may enhance deliberate practice leading to beneficial changes in the entrepreneur's business.

The next section reviews previous research on the association between deliberate practice and effectuation and/or causation in entrepreneurial decision-making.

\subsection{Positing links between effectuation, causation, and deliberate practice}

Without specifically positing or testing links between effectuation/causation and deliberate practice, earlier research has touched on issues that suggest such potential links are worth investigating. For example, researchers such as Baron \& Henry (2010) have shown that, via a range of cognitive routes, expertise gathered through deliberate practice contributes to the effective use of both effectuation and causation. (Baron \& Henry 2010). Corbett (2007) highlights that the way previous knowledge is 
acquired and processed contributes to opportunity discovery. Similarly, Mueller and Shepherd (2016) show that entrepreneurs who can transform the experience of failure into learning are more successful in subsequent opportunity identification. Read and Sarasvathy (2005) show that preference for effectuation increases as entrepreneurs gain expertise, and Dew et al. (2015) indicate that entrepreneurial expertise improves the situational use of control strategies. Read and Sarasvathy (2005) describe some effectuation activities and argue that they could be rehearsed. In sum, Sarasvathy and other researchers argue both that effectuation is a means of acquiring expertise (e.g., Read \& Sarasvathy 2005), and that effectuation is preferred by experts more than novices (Dew et al. 2009; Read et al. 2009; Read \& Sarasvathy 2005). However, Arend et al. (2016, p. 552) argue that increased expertise ought to reduce uncertainty thus reducing the need to apply effectuation processes. In the light of this, it seems useful to explore whether and how effectuation, causation, or both in combination, facilitate deliberate practice among entrepreneurs.

In this study we aim to test the potential relationship between effectuation/causation and deliberate practice in a novel group - credit-enabled entrepreneurs in a developing country context - and, if it is demonstrated, to show how these practices manifest themselves 'on the ground' in that environment. To our knowledge only Baron and Henry (2010), Keith et al. (2016), and Unger et al. (2009) have studied deliberate practice in the entrepreneurship domain, and none of them sought to see whether effectuation (or causation) linked to deliberate practice. In other words, whether and how specific business tasks could be practiced, and whether this practice was influenced by effectuation (or causation) has not been examined before. In addition, as mentioned earlier, we focus on whether doing more (or specific elements of) deliberate practice as a result of effectual and/or causal decision making create beneficial changes in micro-entrepreneurs' business activities.

\subsection{Previous research on effectuation in microfinance}

Effectuation has been studied within the microfinance entrepreneurship domain. For example, Sarasvathy (2008) showed how the formation of the Grameen Bank and its pioneering micro-lending model reflect the use of effectuation principles. Lingelbach et al. (2015) studied financial innovations including microfinance in emerging economies, showing how effectuation principles characterize and facilitate these innovations. However, these studies focussed on institutions. By contrast, this study considers individual microfinance borrowers, the detail of their use of effectuation, causation and deliberate practice, and the resulting changes in their businesses.

\subsection{Defining micro-entrepreneurs and their businesses}


Definitions of entrepreneurship are not uniform. While entrepreneurship typically evokes the idea of starting a new business (Shane 2012), the term is often used more broadly to include discovery and creation of opportunities resulting in new products or services, new markets, new production processes or raw materials, and new ways of organizing technology (Baron \& Shane 2008; Shane 2012; Shane \& Venkataraman 2000). Thus the idea of some kind of novelty or innovation is often implied in the term 'entrepreneurship'. Whether 'entrepreneurship' must imply an intention to grow the new business is also controversial, and has been disputed by feminist researchers in particular (see Ahl 2006; Ahl \& Marlow 2012; and Vadav \& Unni 2006). Here, following Baron and Shane (2008) and Shane (2012), we define entrepreneurs simply as those who create a new business venture.

Among different types of entrepreneurs, we focus on micro-entrepreneurs. In this study, we use a different definition of micro-entrepreneur from some others. Our reasons for doing so follow. Studies of micro-entrepreneurs commonly define them in terms of the size of their enterprises. That is, businesses are categorized as micro, small, medium, or large, depending on one or more size measures such as the number of employees, value of venture assets, turnover, formal/informal business status. By default, the people who start micro-businesses (the smallest category) are called micro-entrepreneurs, that is, the definition of the entrepreneur is elided with the size of their business. Examples of this nomenclature from studies in a range of countries appear in Table 2.

Table 2: Definitions of micro-entrepreneurs derived from (micro) business size

\begin{tabular}{|c|c|c|}
\hline Study & Context & $\begin{array}{l}\text { Definitional criteria for micro-business and/or micro- } \\
\text { entrepreneur }\end{array}$ \\
\hline Allet (2015) & El Salvador & $\begin{array}{l}<10 \text { employees } \\
\text { Informal ventures including business such as small-scale } \\
\text { manufacturers, traders, service providers, artisans, and } \\
\text { farmers }\end{array}$ \\
\hline $\begin{array}{l}\text { Asian } \\
\text { Development Bank } \\
\text { (1997) }\end{array}$ & $\begin{array}{l}\text { Studies } \\
\text { covering } 7 \\
\text { Asian } \\
\text { countries }\end{array}$ & $\begin{array}{l}<10 \text { workers including the owner-operator and family } \\
\text { workers } \\
\text { Non-crop ventures }\end{array}$ \\
\hline $\begin{array}{l}\text { Ayyagari et al. } \\
(2005)\end{array}$ & $\begin{array}{l}\text { Studies by the } \\
\text { World Bank }\end{array}$ & $\begin{array}{l}<10 \text { employees, annual turnover }<\text { USD 100,000, and total } \\
\text { balance sheet value of }<\text { USD } 100,000\end{array}$ \\
\hline Bravo et al. (2013) & Chile & $\begin{array}{l}\text { Up to } 10 \text { employees } \\
\text { No more than EUR } 97,000 \text { annual income }\end{array}$ \\
\hline $\begin{array}{l}\text { De-Mel et al. } \\
\text { (2009) }\end{array}$ & Sri Lanka & $\begin{array}{l}<100,000 \text { Sri Lankan rupees (SLR) in capital, excluding land } \\
\text { and buildings }\end{array}$ \\
\hline $\begin{array}{l}\text { European } \\
\text { Commission (2016) }\end{array}$ & N/A & $\begin{array}{l}<10 \text { employees and an annual turnover or balance sheet of } \\
<\text { EUR } 2 \text { million }\end{array}$ \\
\hline Montes Rojas \& & Argentina & Own-account workers and owners of firms with $<16$ \\
\hline
\end{tabular}




\begin{tabular}{lll}
\hline Siga (2009) & & employees \\
\hline $\begin{array}{l}\text { Omar \& Ishak } \\
\text { (2016) }\end{array}$ & Malaysia & Informal ventures as street retailing and food hawkers \\
\hline Otoo et al. (2012) & Nigeria & Informal ventures as street food vendors \\
\hline Thapa (2015) & Nepal & Up to 9 employees \\
& & $<2,000,000$ Nepal Rupees (NRs) in annual financial \\
& & transactions \\
& Has a fixed investment of maximum NRs 200,000 excluding \\
& & the house or land \\
& & Uses less than ten kilowatts power/energy \\
& & Does not need a license or permission to operate \\
\hline Walsh (2014) & Thailand & Street vendors \\
\hline
\end{tabular}

Size measures are also sometimes combined with other perspectives to define micro-entrepreneurs. For example, Cahn (2008) used a sustainable livelihood perspective and defined microentrepreneurs as small income earning ventures, managed and operated by the owner with the help of his or her family to achieve sustainable livelihood outcomes for the entrepreneurs and their families. The result is that, while these and other studies consistently refer to 'micro-entrepreneurs', the varying definitions of this term limit the studies' generalizability and make their results difficult to compare. This is apart comparability problems potentially created by the studies' varying cultural contexts.

In contrast to these size definitions, and in line with our focus on exploring microfinance borrowers in Sri Lanka, we use the term micro-entrepreneur in the same 'contextual' way that Banerjee and Duflo (2011) use it in their influential critique of microfinance philosophy and practices, namely to denote recipients of microfinance loans who own businesses. The work of Banerjee and Duflo influences our definitional assumptions in another way. Specifically, Banerjee \& Duflo (2011) (as well as Banerjee et al. (2015), Bateman (2010), and Karlan \& Zinman (2011)) found that microfinance loan recipients tend to use their loans for consumption rather than business purposes and that this was one reason their businesses almost always remained small. In recognition of this, we set aside whether a micro-entrepreneur's loan may have been used for consumption purposes. Although we inquired whether the micro-entrepreneur's loan had been used to start the business (see section 5) we did not ask whether part of it had also been used for consumption, or use this issue to exclude participants, because we wanted to explore the business expertise acquisition process in the MFI loan context regardless of the specific purpose/s for which the loan or part of it had been used.

Nevertheless, while we are concerned with micro-entrepreneurs as defined by their having received 
a microfinance loan and owning a business, and we are not directly concerned with firm size, our sample has some features in common with micro-entrepreneurs as variously defined in Table 2 . Microfinance borrowers, like micro-entrepreneurs as defined in Table 2, typically have very small businesses (Gomez \& Santor 2001) with mostly family members working in them, often children and adolescents (Canadian International Development Agency 2007). They typically have survival objectives in addition to economic ones (Shaw 2004). Moreover, despite microfinance institutions (MFIs) recognising them as business entities, most MFI-funded businesses are informal (Akpalu et al. 2012; Beck et al. 2017; Bernasek 2003), that is, they are unregistered, non-tax-paying entities (Jütting and de Laiglesia 2009). This means that our findings for micro-entrepreneurs - defined as recipients of microfinance loans with business - are likely to have at least some points of comparability with findings about micro-entrepreneurs defined in terms of business size.

The next section briefly describes the Sri Lankan national context and the Hope Microfinance Institute $(\mathrm{HMI})^{1}$, the MFI whose borrowers we sampled for the study.

\section{The context: Sri Lanka and the Hope Microfinance Institute (HMI)}

Sri Lanka is a lower middle-income country with $77 \%$ of its 20.7 million people living in rural areas (Central Bank of Sri Lanka 2015; Department of Census and Statistics: Sri Lanka 2013; The World Bank 2015). Both agriculture and non-agriculture related activities are concentrated in rural areas where the informal sector accounts for $59.5 \%$ of total employment (Department of Census and Statistics: Sri Lanka 2014). A number of different MFIs finance and support micro-enterprises (GTZ ProMiS 2010; The World Bank 2006). There is increasing national policy level engagement in microfinance and micro and small enterprise (MSE) development in terms of new regulations and the establishment of supporting structures (Central Bank Sri Lanka 2015; GTZ ProMiS 2010). Thus Sri Lanka provides a typical developing country context in which to study our research questions.

Several studies, not confined to microcredit borrowers, provide insights into the business development and decision-making process among micro-entrepreneurs in Sri Lanka. For example, Kodithuwakku and Rosa (2002) explored the entrepreneurial process and business success among villagers in an irrigation settlement in an arid part of the country using a multiple embedded case study method. They found that business success depended on the creative and persistent nature of entrepreneurs, that is, those who were more creative in identifying opportunities, mobilizing resources, and forming and using their social network were more successful. In addition, De-Mel et al. (2009) used a randomized experiment with a one-time grant as the intervention and found long

\footnotetext{
${ }^{1}$ A pseudonym.
} 
lasting gender-based business effects. In particular: a) women invested large grants but their returns did not change, and b) men invested both small and large grants and their returns increased. They posited that the difference lay in the fact that female-dominated industries were overall less lucrative than male-dominated industries, and that women business owners faced competing household demands. De-Mel et al. (2011) found that providing product-specific credit information such as interest rate, terms and conditions, and repayment structure increased the use of institutionalized credit. Shaw (2004) studied micro-entrepreneurs attached to two MFIs, a target group similar to this study, and examined the income-related impact gap among them. She found that poorer clients faced geographic, financial, and sociocultural barriers to entry to the most promising microenterprise occupations, leading them to select low-value activities with poor growth prospects. In contrast, in semi-urban areas, poverty impacts could be reduced by supplementing loans with nonfinancial interventions to encourage poor clients to select higher-value occupations. While these studies address a variety of micro-entrepreneurship issues in a developing country, they do not address the expertise acquisition process and the extent to which it changes business practices.

To explore our research questions, we used a sample of HMI borrowers who own businesses (termed micro-entrepreneurs here-see section 2.5). HMI, according to its 2014 annual report, focuses on poverty reduction and institutional sustainability and provides both microfinance loans and enterprise development services; the latter were used by 22,400 clients in 2014 . At the time of data collection, HMI had 18 branches across four provinces in Sri Lanka serving around 66,000 borrowers of whom $80 \%$ were women. Although some studies, such as Asian Development Bank (1997) and Shaw (2004), distinguish between livelihood-oriented and growth-oriented microenterprises, there was no information in HMI that would allow us to separate the two categories. However, HMI's annual reports indicate that, like most MFIs, HMI tries to help businesses become viable growth-oriented entities. For example, in 2014, HMI helped launch more than 120 different types of micro-enterprises, promoted business expansion, and transformed micro-businesses into SMEs. Annual reports from 2011 through 2014 include success stories of clients who used their loans and HMI's enterprise development services to expand, improve and modify their businesses. Every two years HMI recognizes the 'best' entrepreneurs across a range of categories: small business, micro-business, upcoming entrepreneur, agriculture, and animal husbandry with criteria based on employment generation and use of credit and enterprise development services. Thus, unpacking entrepreneurial processes and exploring how micro-entrepreneurs gather expertise could suggest ways to improve MFI interventions. 
According to its operational manual and annual reports, HMI provides loans for business start-up and development, agriculture, dairy purposes, and asset building such as building a house or buying assets such as motorcycles, electronic equipment, or three-wheelers. Enterprise development services include training in cultivation practices (e.g., papaya and onion growing, mushroom cultivation and sales), and cattle and poultry management), and non-agriculture training programs (e.g., food processing, dressmaking, and production of candles, detergents, handicrafts, and rugs), skill development programs (e.g., motivation and positive thinking), visits to key agricultural research institutions to educate borrowers in new technologies, and other business support services such as creating market linkages and managing business registrations. These loan and enterprise development services are provided via community groups termed clusters. A cluster is an informal group consisting of 30-33 borrowers made up of 10-11 peer groups (i.e., three borrowers who guarantee each other's loans) which act as loan collection units in the village. Every branch has around 150-165 clusters serviced by 4-5 field officers (i.e., 30-33 clusters per officer). This HMI cluster system is similar to the solidarity group lending approach used by MFIs such as the Grameen Bank in Bangladesh, where peers guarantee and monitor each other's loans (Ledgerwood \& Earne 2013). Thus while this study focuses on a Sri Lankan MFI, its findings and their policy implications may have wider applicability.

\section{Method}

We used a mixed method approach - a survey and interviews - to gather data. In the entrepreneurship domain, methodological plurality is recommended due to the complex and multifaceted nature of entrepreneurial phenomena (Davidsson 2004; Molina-Azorín et al. 2012; Neergaard \& Ulhoi 2007). Although effectuation has undergone theoretical and empirical development (Perry et al. 2012), the relatively under-explored and complex nature of our research questions also suggested the use of mixed methods. The survey enabled us to identify broad trends and patterns in micro-entrepreneurs' use of effectuation, causation, and deliberate practice. We supplemented the quantitative analysis with in-depth interviews to help us to pinpoint specific features of the business activities underpinning those trends.

\subsection{Quantitative data collection and analysis}

To provide a spread of loan recipients in the sample, one branch from each MFI province was selected (HMIs' 18 branches are located in four different Sri Lankan provinces with four or five branches per province). From each branch 11-12 clusters were selected randomly. One of the researchers, a native speaker of Sinhalese, visited the clusters, explained the research, and invited 
borrowers who owned businesses to participate in the study. Respondents were invited to complete the questionnaire during a cluster meeting. Given our interest in businesses which had the capacity to grow, at this point we screened out crop cultivators due to the subsistence nature of most cultivation operations, the heavy government subsidies they receive (Ministry of Finance Sri Lanka 2014), and the small size of land holdings which prevents most crop cultivators from becoming commercial businesses. However we included businesses in mushroom cultivation and selling, commercial poultry farming, owning and managing fishing boats, and dried fish processing where these issues do not arise. As the clusters were selected randomly, some cluster meetings occurred at the same time. In such instances, the MFI field officer, who had been trained in the data collection process, distributed the questionnaires and collected completed ones. Respondents were given written information about the purpose and voluntary nature of the research, and the researchers' contact details in case of questions. This process resulted in a sample of 295 respondents.

The questionnaire had two main sections. The first sought demographic information such as the respondent's sex, age, education level, and characteristics of the business such as type of product/service, whether a microloan had been used to start the business, whether the main business was the respondent's first business, and whether the respondent had had previous business experience. The survey took account of the fact that some respondents had started more than one business. In such cases we asked them to think of their 'main business', defined as the one they had managed the longest, when answering the questions. Most questions had closed-ended options with very simple wordings and explanations to allow for low literacy levels. For example when we asked whether a respondent's main business was their first business, or whether they had previous business experience, we had dichotomous answer categories: yes or no. When we asked about the total value of the business assets, we used examples such as machinery, equipment, finished products, and raw materials, and included five categorical answer options ranging from $<50,000$ SLR to $>1,000,000$ SLR.

The second category of questions asked about the nature and extent of respondents' effectual and causal thinking, and their use of deliberate practice during the start-up phase of their business. Rather than using pre-determined measures of the early developmental phases of the business, the questionnaire allowed respondents themselves to define what they considered to be the events and activities of the early, start-up phase of their business. Existing effectuation and causation scales developed by Chandler et al. (2011) were adapted slightly to suit the microfinance context. For example, we explained some terms which might not be familiar to micro-entrepreneurs (e.g., Original statement: We experimented with different products and/or business models. $\underline{\text { Adapted }}$ 
statement: I experiment with different products and/or ways of doing business). In addition, following Werhahn et al. (2015) who developed an effectual scale for large corporations, we added items related to networks, resources, and available knowledge to measure means-driven approaches, and items related to experimentation. As Chandler et al. (2011) had found only marginal reliability (i.e., Cronbach's $\alpha$ of 0.62 ) in their pre-agreements/alliances sub-scale, we added one statement to this dimension. Our deliberate practice scale used Ericsson's (2006; 2008) items: a) clear performance improvement goals, b) motivation to improve, c) seeking feedback, d) use of opportunities to practice, and e) reflection and refinement of specific practices. We ensured that all Ericsson's key words were reflected in our statements (see Annexure 1 - Statements used in the deliberate practice scale) and verified this with academics before use. The original deliberate practice scale had six statements, but due to reliability concerns (i.e., low Cronbach $\alpha$ values after item deletion), we used only five statements. The questionnaire was translated and back-translated into the local languages of Sinhalese and Tamil, and pre-tested before use.

Because we collected data for independent and dependent variables using the same instrument, we used several strategies to minimize common method bias arising from social desirability (i.e., responses that reflect participants' knowledge of accepted business norms rather than their actual behaviours) and common scale format (i.e., having a Likert scale with same number of categories for both effectual/causal scales and deliberate practice) (Podsakoff et al. 2003). We minimized the potential for common method bias by allowing respondents to answer anonymously. In addition, we emphasized that there were no right and wrong answers, and carefully ordered the statements in the effectuation, causation, and deliberate practice scales to avoid pre-empting socially desirable responses.

The survey data analysis, for which we used SPSS, had several steps. First, we used descriptive statistics (i.e., frequencies and percentages) to summarize respondents' basic demographic and business details. We then described respondents' use of effectuation, causation and deliberate practice. Only responses from individuals with less than $20 \%$ of missing data were used (Downey \& King 1998), and the mean score per person was used to minimize the effect of missing data (De Vaus 2014). As effectuation is a formative scale with four reflective sub-scales and causation is a reflective unidimensional measure (Chandler et al. 2011), we report the mean values for effectuation using the four dimensions and a single dimension for causation. The causation scale was considered reliable with Cronbach's $\alpha$ of 0.78 and the causation statements loaded onto one factor with loadings of 0.33 to 0.76 . Similarly, our deliberate practice statements loaded onto a single factor with factor loadings 
of 0.61 to 0.79 ; the Cronbach's $\alpha$ was 0.82 . However, in the effectuation scale, although four clear factors were extracted, the statements identified by Chandler et al. (2011) did not load cleanly onto the corresponding factors. This may be because of conceptual similarities in the effectual dimensions. In addition, all the sub-scales were only marginally reliable with Cronbach's $\alpha$ values ranging from 0.65 to 0.70 . Furthermore, we conducted a Herman's single factor test (Podsakoff et al. 2003) to check whether our analysis was affected by common method bias. We found that only $34 \%$ of the variance was explained by the single factor, indicating that common method bias did not pose a threat to our findings.

Finally, we used ordered logistic regression to test whether respondents' use of the five deliberate practice elements was influenced by their use of effectuation and causation logics. We found no multicollinearity issues in the effectuation and causation scales with tolerance values ranging from 0.42 to 0.82 and VIFs between 1.20 and 2.36. In addition, we controlled for the effects of business size (via the value of assets in the business), the duration of the business, and the respondent's age.

\subsection{Qualitative data collection and analysis}

Interview data from 24 microfinance entrepreneurs (all women) who were not part of the survey group was gathered using a purposive sampling technique. One of the researchers asked MFI branch staff to recommend borrowers who owned businesses and who might like to tell their business story. The branch staff contacted the selected borrowers (mostly by phoning them) and then the researcher visited them (alone), arranged a convenient time to talk, obtained consent, and conducted the interview. This process ensured that participant interviews were done voluntarily. All interviews were conducted face-to-face by the researcher at the interviewee's business premises; for most interviewees, household and business were at the same location. Five to seven interviews per branch (from four branches) were conducted. Information was gathered about each entrepreneur's 'business story', in particular their activities during the pre-start-up, start-up, and development phases of the business (see Annexure 2: Interview protocol). All but one interview was conducted in Sinhalese; an interpreter assisted with the remaining interview which was conducted in Tamil. The interviews lasted for 20-30 minutes each, and were voice recorded, transcribed, and translated into English, and the data entered into NVivo.

The qualitative data analysis using NVivo began with the researchers identifying themes and incidents from the interviewees' stories which resembled effectual/causal decision-making or deliberate practice actions or both. The items were grouped on tree nodes corresponding to the 
principles of effectuation, causation, and deliberate practice. We then looked for patterns in the data, for example, incidents where, say, an incident categorized as effectual thinking linked to one or more forms of deliberate practice. We compared these patterns with our findings from the survey findings to explain those findings and/or to understand how they manifested themselves in day-today practices. Thus rather than allowing new associations to be uncovered, the qualitative data primarily provided 'colour and texture' for the quantitative findings.

\section{Results}

We first report demographic details of our respondents and features of their businesses, and describe their use of effectuation, causation, and deliberate practice. We then present the results of the ordinal logistic regression analysis with which we tested whether using effectuation or causation logics influenced specific elements of deliberate practice.

\subsection{Demographic profile of survey respondents and their businesses}

The majority of survey respondents were women ( $84.5 \%$ of 295$)$. This percentage is typical as MFIs, following the experience of the Grameen Bank, focus on women borrowers (Rahman \& Nie 2011; Wahid 1999). The largest segment (36.2\%) of the survey respondents was aged 31 to 40 years, followed by respondents aged 41 to 50 years (20.6\%). In addition, $59.4 \%$ of the respondents had year 6 to O-Level education with only $26.8 \%$ educated to year 12 or above. See Table 3 . 
Table 3: Age and education of respondents

\begin{tabular}{|c|c|c|c|c|c|}
\hline \multicolumn{3}{|c|}{ Age of respondents $(\mathrm{N}=287)$} & \multicolumn{3}{|c|}{ Education of respondents ( $\mathrm{N}=\mathbf{2 8 3})$} \\
\hline Age category & $\#$ & $\%$ & Education level & $\#$ & $\%$ \\
\hline $18-30$ years & 56 & 19.5 & No schooling & 3 & 1.1 \\
\hline$>30$ to 40 years & 104 & 36.2 & Year 1 to 5 & 36 & 12.7 \\
\hline$>40$ to 50 years & 85 & 29.6 & Year 6 to $\mathrm{O} / \mathrm{L}$ & 168 & 59.4 \\
\hline$>50$ years & 42 & 14.6 & Year 12 \& above (i.e. university) & 76 & 26.8 \\
\hline Total & 287 & $100 \%$ & Total & 283 & $100 \%$ \\
\hline
\end{tabular}

The respondents managed businesses in a variety of industries. As Table 4 shows, businesses in agriculture, animal husbandry, and fisheries-related industries (32.2\%); specialized services (20\%); production-related businesses (17.3\%); and unspecialized retail sales (17.3\%) were common.

Table 4: Industries represented in the sample $(\mathrm{N}=\mathbf{2 1 4})$

\begin{tabular}{lrr}
\hline \multicolumn{1}{c}{ Type } & $\#$ & $\%$ \\
\hline Agriculture, animal husbandry or fisheries related business & 69 & 32.2 \\
Production businesses (e.g., clay, cement, food) & 37 & 17.3 \\
Retail and wholesale sales & 21 & 9.8 \\
Specialized retail sales (e.g., garments, mobiles, ornaments) & 37 & 17.3 \\
Unspecialized retail sales (e.g., grocery shops) & 7 & 3.3 \\
Wholesale businesses & 43 & 20.0 \\
Specialized services (e.g., tailoring, wood cutting, construction) & $\mathbf{2 1 4}$ & $\mathbf{1 0 0}$ \\
\hline \multicolumn{1}{c}{ Total } & \\
\hline
\end{tabular}

Of the respondents, $85.3 \%(\mathrm{~N}=259)$ reported that their main business, defined as the business that they had managed or were managing for the longest time, was also their first-ever business venture. For the remaining $14.7 \%$, their main business was the second or subsequent business they had started. In addition, $31.8 \%, 26.6 \%$ and $24.0 \%$ of the respondents had managed their main business for $\leq 2$ years, $>2$ to 5 years, and $>10$ years respectively (see Table 5 ). 
Table 5: Business size and age

\begin{tabular}{lccccc}
\hline \multicolumn{2}{c}{ Size of the business (N=239) } & \multicolumn{3}{c}{ Age (N=267) } \\
\hline \multicolumn{1}{c}{ Business size (SLR) } & $\#$ & $\%$ & Duration & \% & 85 \\
\hline$\leq 50,000$ & 95 & 39.7 & $\leq 2$ years & 71 & 26.6 \\
$>50,000$ to 150,000 & 104 & 43.5 & $>2$ to 5 years & 36 & 13.5 \\
$>150,000$ to 500,000 & 28 & 11.7 & $>5$ to 7 years & 11 & 4.1 \\
$>500,000$ to $1,000,000$ & 8 & 3.3 & $>7$ to 10 years & 64 & 24.0 \\
$>1,000,000$ & 4 & 1.7 & $>10$ years & $\mathbf{2 6 7}$ & $\mathbf{1 0 0 \%}$ \\
\hline \multicolumn{1}{c}{ Total } & $\mathbf{2 3 9}$ & $\mathbf{1 0 0 \%}$ & Total & &
\end{tabular}

*SLR: Sri Lankan Rupees

Table 5 shows that although nearly a quarter of respondents had managed their businesses for more than 10 years, more than half (58\%) had started their business during the last five years. This was to be expected given that women often engage in livelihood activities only after their child-bearing years (Kevane $\&$ Wydick 2001). The survey data also found that $61 \%$ of respondents had used all or part of a microfinance loan in addition to other sources of finance to start their main business. The remainder had already started their main business before receiving the loan.

\subsection{Interviewees}

Of the 24 interviewees, all but two were women. Most were engaged in food production, dressmaking and garment sales, or agriculture-related businesses. Table 6 provides an overview of the interviewees and their main business. 
Table 6: Interviewee profiles

\begin{tabular}{|c|c|c|c|}
\hline $\begin{array}{l}\text { Interview } \\
\text { no. }\end{array}$ & Gender & Owner (or part-owner) of a... & $\begin{array}{l}\text { Approximate business } \\
\text { start-up time }\end{array}$ \\
\hline 1 & Female & $\begin{array}{l}\text { Vehicle upholstery business (part-owner with } \\
\text { her husband) }\end{array}$ & Five years ago \\
\hline 2 & Female & Cake-making business & 19 years ago \\
\hline 3 & Female & Snacks and confectionery making business & A year ago \\
\hline 4 & Female & Multi-day fishing boat & Four years ago \\
\hline 5 & Female & Garment sales business & Five years ago \\
\hline 6 & Female & Confectionery making business & Five years ago \\
\hline 7 & Female & Grocery shop and milk collection centre & Six years ago \\
\hline 8 & Female & Dressmaking business & More than 10 years ago \\
\hline 9 & Female & Mobile tea selling business & Less than a year ago \\
\hline 10 & Female & $\begin{array}{l}\text { Pillowcase and cement flowerpot making } \\
\text { business }\end{array}$ & A year and half ago \\
\hline 11 & Male & Mobile toys, sweets and fruit selling business & More than 10 years ago \\
\hline 12 & Female & Dressmaking business & More than 20 years ago \\
\hline 13 & Female & $\begin{array}{l}\text { Business providing carpets and packing snack } \\
\text { foods and lamp wicks }\end{array}$ & A year ago \\
\hline 14 & Female & Grocery shop & 10 years ago \\
\hline 15 & Female & Dressmaking business & 15 years ago \\
\hline 16 & Female & $\begin{array}{l}\text { Dressmaking business under a forward sales } \\
\text { agreement }\end{array}$ & Just over a year ago \\
\hline 17 & Female & Dressmaking and garment sales business & 15 years ago \\
\hline 18 & Female & Mushroom cultivation and sales business & 10 years ago \\
\hline 19 & Female & Bra-making business & 10 years ago \\
\hline 20 & Female & Cut-flower and nursery business & Six years ago \\
\hline 21 & Male & Plant nursery & More than 10 years ago \\
\hline 22 & Female & Cut-flower business & 10 years ago \\
\hline 23 & Female & $\begin{array}{l}\text { Kithul [a type of palm tree] treacle and jaggery } \\
\text { [a type of palm sugar] making business }\end{array}$ & More than 10 years ago \\
\hline 24 & Female & Confectionery making business & Three years ago \\
\hline
\end{tabular}

Businesses that were founded five years ago or less are shaded. 


\subsection{Micro-entrepreneurs' use of effectual and causal thinking}

With means ranging from 3.58 to 3.99 , micro-entrepreneurs made strong use of both effectuation and causation thinking during business start-up. See Table 7.

Table 7: Use of effectual and causal thinking at business start-up

\begin{tabular}{llc}
\hline & Mean & Standard error \\
\hline Effectuation & 3.95 & \\
Means-driven approaches $(\mathrm{N}=212)$ & 3.86 & 0.04 \\
Affordable loss thinking $(\mathrm{N}=213)$ & 3.58 & 0.06 \\
Pre-agreements/alliances ( $\mathrm{N}=196)$ & 3.95 & 0.07 \\
Acknowledging the unexpected (N=206) & 3.99 & 0.05 \\
Causation (N=200) & & 0.05 \\
\hline
\end{tabular}

Interview findings about use of effectuation and causation

The qualitative data provided evidence about how effectual and causal thinking worked "on the ground". We discuss both logics, beginning with effectuation, and use E (for effectuation) or C (for causation) with the name of the principle to identify how respondents used each approach.

Interviewees used effectuation frequently. For example, interviewee 2 had gradually "slid" into the business from very small beginnings ( $E$ : what I know):

I used to make cakes for my son and other children. I made some cakes for my friends [...] Then I thought I would make one birthday cake. If it worked, I would continue. I made cakes for a few people; I made one cake, and then two, then three. Like that the business took off gradually (Interviewee 2, cake-making business).

The same interviewee had learnt to make cakes from a relative, that is, someone in her network ( $E$ : using available means). Similarly interviewee 19 , who started a bra-making business, first tried out sewing bras at home (E: using available means), then sold them to neighbors, getting feedback from her network (E: means-driven approaches 'whom I know'). She also used previous knowledge gained from working in a tailor's shop (E: using available means: 'what I know') Interviewee 11 had also learnt his trade by working with his father:

In 1992-93, I was around 13 or 14 years old. From that time, I went with my father. My father sold toys of animals made of wool here [referring to one of the famous Buddhist 
temples situated near a pilgrimage route]. I got used to the business by coming with him (Interviewee 11, a mobile seller of toys, sweets, and fruits).

The interview data also showed the importance of the entrepreneur's social network in helping start the business (e.g., interviewees 1, 3, 17, 18, and 24):

My husband knew a driver who worked near the harbor. He has connections with different people who bring goods in and out of the harbor (E: pre-agreements/alliances). Someone had asked this driver to recommend someone who could re-cushion the seats of a passenger ship. So the driver immediately called my husband and asked him to come the next day, so that the work could be discussed (Interviewee 1, a part-owner of a vehicle upholstery business).

The interviewees used money they already had or found other inexpensive ways to start a business. That is, they invested what they could afford to lose. For example, interviewee 2 started her cakemaking business by selling her jewellery and buying only the most necessary equipment, limiting potential losses (E: Affordable loss). Interviewees 1 and 16 used capital only loans, which have no fixed repayment structure, from a family member and a friend respectively (E: Affordable loss). Interviewees 12 and 8 bought sewing machines on an instalment plan (E: Affordable loss). Interviewee 20 used family labor instead of hiring external employees (E: Affordable loss). Interviewee 24 used current income from selling vegetables ( $E$ : Affordable loss) to start her main business:

I used the income from vegetable sales to start this business. I did not have a large sum of money with me when I started the business. I just initiated this business with the money I had (Interviewee 24, a confectionery business owner).

Pre-agreements were also evident among interviewees, especially securing customer orders. For example, interviewees 8,15 , and 17 made garments and pre-school uniforms based on customer orders (E: pre-agreements/alliances). Interviewee 5 supplied party dresses from Colombo [the capital of Sri Lanka] when customers pre-ordered them (E: pre-agreements/alliances). Interviewee 6 obtained customer orders to provide snack food ( $E$ : pre-agreements/alliances). Almost all these were short-term contracts or agreements, hence cash flow fluctuated:

We [the interviewee and her husband] have orders to provide food. These orders are irregular and not fixed. So, cash inflow is not stable and it can fluctuate (Interviewee 6, a confectionery business owner). 
In addition, forming agreements required negotiations to avoid spending too much money at the outset. For example, interviewee 1 negotiated terms and even asked for a monetary advance (E: Affordable loss):

For that [re-cushioning the seat of the passenger ship], I needed 50,000 rupees upfront. [...] Before the work, two officers came for an inspection as well. I asked my husband to explain to the officers that we needed 50,000 rupees for rexins [type of leather], the materials, and our initial expenses. Then, we explained everything and they agreed to buy all the rexins and other materials for us from Colombo. They asked us just to quote for our labor. In the end we asked for 120,000 rupees as labor charges (Interviewee 1, part-owner of a vehicle upholstery business).

Interviewees also acknowledged the unexpected and changed problems into opportunities by being flexible and adaptive in their business. For example, an unexpected event led to interviewee 22's cut-flower business:

[...] We [the interviewee and her husband] received that [a small poly-tunnel] to start a vegetable plant nursery [from the government]. Around 20 people in Kothmale [an administrative division of Sri Lanka] received these tunnels. We thought if all these people started vegetable plant nurseries, there would be marketing problems. So, we abandoned that idea (E: Affordable loss). Then we thought of planting flowers (E: Acknowledging the unexpected) (Interviewee 22, a cut-flower business owner).

In addition, interviewee 3 and 11 adapted their business according to seasonal changes and customer demand:

These days I cannot have toys here [near the pilgrimage route], as it is raining (E: Acknowledging the unexpected). It is this [selling sweets], I can do. Further, toys do not work now [this time of the year]; it is good in school holiday seasons. For this holiday, usually older people come. For this, Dosi [a sweet] and mangoes are the ones to sell (E: Acknowledging the unexpected) (Interviewee 11, a mobile seller of toys, sweets, and fruits).

Some interviewees used causation thinking as well as effectuation thinking. For example, interviewees had plans, albeit short-term ones, such as to establish a net house for orchids ( $C$ : Causation) (interviewee 20), extend their business premises (C: Causation) (interviewee 14), establish a paddy parboiler ( $C$ : Causation) (interviewee 7$)$, and buy a vehicle ( $C$ : Causation) 
(interviewee 9). Interviewee 24 calculated expected revenue ( $C$ : Causation) by keeping records about her expenses and then calculating her likely income by comparing the price of a jujube packet [a sweet] in the market with her price for a similar product. Interviewee 19 analysed market trends (C: Causation) and new styles by studying the catalogues of well-known lingerie brands. The same interviewee inspected her competitors' products to identify her competitive advantage ( $C$ : Causation). Moreover, these interviewees had taken out microfinance loans, and planning, goal setting and calculating returns were used both when they obtained the loans and when they repaid them:

[When obtaining microfinance loans] I plan what to buy (C: Causation). When I plan, I decide how much loan money is required (C: Causation) (Interviewee 8 , a dressmaker).

When ploughing land per acre, it costs around 7,000 [SLR]. So we [the interviewee and her husband] can earn around 50,000 to 60,000 [SLR] per month by ploughing. The tractor only costs 55,000 [SLR]. So, we can earn a return and also pay the loan instalment (C: Causation) (Interviewee 7, owner of a milk collecting centre and a grocery shop).

Thus although survey evidence shows respondents use both effectuation and causation during startup, the interview evidence suggests that effectuation thinking is more prominent. This could partly be an artefact of the data collection technique: the serendipitous events associated with effectuation may have been more salient to the interviewee and more interesting to talk about than goal setting. It could also be partly due to the respondent's gender: the sample included mainly women who are more likely than men to use family and their immediate network as a means to start a business. Women also typically have to overcome greater challenges than men when starting a business (Ahmad 2011; Erogul et al. 2016; Kodithuwakku \& Rosa 2002).

\subsection{Micro-entrepreneurs' use of deliberate practice}

The overall mean of 4.12 (standard error $=0.05$ ), shows micro-entrepreneurs make strong use of deliberate practice. Of the specific deliberate practice items, respondents appeared to obtain feedback to improve business practices slightly less than some other items (mean $=3.77$ ), but all other deliberate practice items were heavily used. See Table 8. 
Table 8: Mean values for deliberate practice items

\begin{tabular}{lcc}
\hline \multicolumn{1}{c}{ Deliberate practice items } & Mean & Standard error \\
\hline Having clear performance improvement goals & 4.21 & 0.06 \\
Having a motivation to improve the practices & 4.33 & 0.05 \\
Obtaining feedback to improve business practices & 3.77 & 0.07 \\
Use of available opportunities to practice & 4.12 & 0.07 \\
Reflection and refinement of practices & 4.30 & 0.05 \\
\hline
\end{tabular}

\section{Interview evidence about micro-entrepreneurs' use of deliberate practice}

We use the same approach as with effectuation and causation to report the day-to-day reality of how micro-entrepreneurs deliberately practice their entrepreneurial skills, identifying specific deliberate practice dimensions as they appeared in the interview data (e.g., DP: Repetitive practice). The interviews showed a range of informal, self-regulated ways that micro-entrepreneurs engaged in deliberate practice. For example, interviewees 20 and 21 both aimed to increase the number of plants sold in their plant nurseries, and both used repetitive practice to achieve the goal. For example, interviewee 20 expanded her network to identify potential growers, cold-called them to ask if they would grow plants for her, and investigated places where she could buy tissue cultured seedlings (DP: repetitive practice). Interviewee 21 observed what type of plants had higher sales figures, planted more of those, and reduced other varieties (DP: Repetitive practice).

Interviewees also consciously motivated themselves by thinking about their business and future:

It is very difficult to get up early in the morning every day and do the work. But I keep reminding myself that I pay for my children's education from this [business] and I have to do this [business] well to improve my living [standard]. (DP: Motivation) I always remind myself that I am the one who should make my own business a success. No one else can do that. (DP: Motivation) As I continuously thought like that, I got used to getting up early and doing business activities. Then the work became a habit (Interviewee 6 , a confectionery business owner).

Interviewees obtained feedback from informal and formal sources. Using feedback was often combined with reflecting on and refining business practices, and even other aspects of deliberate practice such as repeating activities. For example, interviewee 23 met with government officers to obtain feedback about her products and her business (DP: Using feedback). She also went multiple 
times to trade fairs and exhibitions to showcase her products [palm sugar and honey], pitched her products, and met potential buyers numerous times (DP: Using feedback, Repetitive practice, Reflection and refinement of business practices). Similarly, training programs (e.g., interviewees 8 , 12 , and 24) provided opportunities for micro-entrepreneurs to get ideas from others that they could try out later, carry out specific actions repeatedly, and reflect on and refine how they carried out business tasks. All this was done in a formal, organized setting under the guidance of an instructor/trainer, similar to classical deliberate practice activities such as learning music or sport. Training programs also sometimes meant interviewees could instruct their peers as well as learn things themselves, so deliberate practice (via feedback) became a shared activity:

From there [training sessions], I get new ideas (DP: Feedback). How to do packing, etc. (DP: Performance improvement goals) When I go to a training [session], I share ideas with others (DP: Feedback) and then I can improve myself (DP: Reflection and refinement) (Interviewee 20 , a cut-flower and plant nursery owner).

\subsection{Links between effectuation/causation and deliberate practice}

We used ordinal logistic regression analysis to test whether specific effectuation items or causation influenced specific dimensions of deliberate practice. All the regression equations maintained the parallel lines assumption with $p \geq 0.05$. In addition, Nagelkerke pseudo $r^{2}$ values ranged from 0.40 to 0.57 , indicating that the independent variables explained around $50 \%$ of the variance in different elements of deliberate practice. Furthermore, the analysis indicated that effectual principles and causation thinking affect multiple deliberate practice items, and these are shown in Table 9. Specifically, significant effects are noted between the following: means-driven approaches with having clear performance improvement goals, motivation and repetitive practice; affordable loss thinking with repetitive practice and reflection/refinement; and pre-agreements/alliances with feedback, repetitive practice and reflection/refinement; and acknowledging the unexpected thinking with all five deliberate practice items. Similarly, causation thinking significantly influences having clear performance goals, feedback, and repetitive practice. Furthermore, regression results show that micro-entrepreneurs use feedback and reflect on and refine their business practices, particularly while the business is still fairly young, especially when the business is between two and five years old. Also, using feedback is significantly more important to micro-entrepreneurs whose businesses have a comparatively low asset value $(<150,000$ SLR). See Table 9. 
Table 9: Ordered logistic regression findings of effectuation/causation and deliberate practice items

\begin{tabular}{|c|c|c|c|c|c|c|c|c|c|c|c|c|c|c|c|c|}
\hline & & \multicolumn{15}{|c|}{ Deliberate practice } \\
\hline & & \multicolumn{3}{|c|}{$\begin{array}{c}\text { Performance } \\
\text { improvement goals }\end{array}$} & \multicolumn{3}{|c|}{ Motivation } & \multicolumn{3}{|c|}{ Feedback } & \multicolumn{3}{|c|}{ Repetitive practice } & \multicolumn{3}{|c|}{$\begin{array}{l}\text { Reflection and } \\
\text { refinement }\end{array}$} \\
\hline & & Esti. & SE & Sig. & Esti. & SE & Sig. & Esti. & SE & Sig. & Esti. & SE & Sig. & Esti. & SE & Sig. \\
\hline \multirow[t]{4}{*}{ Effectuation } & $\begin{array}{l}\text { Means-driven } \\
\text { approaches }\end{array}$ & 0.76 & 0.44 & $0.08 *$ & 0.97 & 0.44 & $0.03 * *$ & -0.33 & 0.45 & 0.46 & 1.03 & 0.42 & $0.01 * *$ & 0.60 & 0.45 & 0.18 \\
\hline & Affordable loss & 0.07 & 0.29 & 0.80 & -0.19 & 0.27 & 0.49 & -0.15 & 0.28 & 0.58 & -0.71 & 0.28 & $0.01 * *$ & -0.54 & 0.29 & $0.06 *$ \\
\hline & Pre-agreements & -0.05 & 0.29 & 0.86 & 0.49 & 0.28 & $0.08^{*}$ & 0.70 & 0.29 & $0.01 * *$ & 0.52 & 0.27 & $0.05^{*}$ & 0.39 & 0.30 & 0.18 \\
\hline & $\begin{array}{l}\text { Acknowledging the } \\
\text { unexpected }\end{array}$ & 0.85 & 0.39 & $0.03 * *$ & 0.98 & 0.39 & $0.01 * *$ & 1.52 & 0.40 & $0.00 * * *$ & 0.85 & 0.37 & $0.02 * *$ & 1.05 & 0.41 & $0.01 * *$ \\
\hline \multicolumn{2}{|l|}{ Causation } & 1.61 & 0.45 & $0.00 * * *$ & 0.19 & 0.40 & 0.64 & 1.38 & 0.44 & $0.00 * * *$ & 1.19 & 0.40 & $0.00 * * *$ & 0.56 & 0.42 & 0.18 \\
\hline \multirow{2}{*}{$\begin{array}{l}\text { Assets (in } \\
\text { SLR) }\end{array}$} & $<50,000$ & -0.11 & 0.58 & 0.84 & -0.13 & 0.58 & 0.83 & -1.36 & 0.56 & $0.02 * *$ & 0.61 & 0.54 & 0.26 & -0.57 & 0.57 & 0.32 \\
\hline & $\geq 50,000$ to 150,000 & 0.19 & 0.54 & 0.72 & -0.11 & 0.54 & 0.84 & -1.31 & 0.57 & $0.02 * *$ & 0.33 & 0.50 & 0.51 & 0.07 & 0.53 & 0.90 \\
\hline \multirow{4}{*}{$\begin{array}{l}\text { Business } \\
\text { duration } \\
\text { (years) }\end{array}$} & $<2$ & 0.90 & 0.55 & 0.10 & 0.35 & 0.53 & 0.52 & 1.56 & 0.66 & $0.00 * *$ & -0.68 & 0.51 & 0.18 & 0.56 & 0.53 & 0.29 \\
\hline & $>2$ to 5 & 0.09 & 0.58 & 0.87 & 0.24 & 0.56 & 0.67 & 1.33 & 0.89 & $0.02 * *$ & -0.11 & 0.55 & 0.84 & 1.20 & 0.57 & $0.03^{* *}$ \\
\hline & $>5$ to 7 & 1.06 & 0.73 & 0.15 & -0.55 & 0.65 & 0.40 & 1.17 & 0.66 & $0.08^{*}$ & 1.03 & 0.68 & 0.13 & 0.41 & 0.68 & 0.55 \\
\hline & $>7$ to 10 & 0.83 & 0.91 & 0.36 & 0.80 & 0.90 & 0.38 & 1.10 & 0.87 & 0.21 & -1.04 & 0.82 & 0.20 & 1.74 & 0.94 & 0.06 \\
\hline \multirow{3}{*}{$\begin{array}{l}\text { Age of the } \\
\text { respondent } \\
\text { (years) }\end{array}$} & 18 to 30 & -0.27 & 0.66 & 0.68 & 0.05 & 0.66 & 0.94 & -0.28 & 0.66 & 0.67 & 0.39 & 0.63 & 0.54 & 0.22 & 0.67 & 0.75 \\
\hline & 31 to 40 & -0.48 & 0.59 & 0.42 & -0.05 & 0.59 & 0.93 & -0.14 & 0.60 & 0.81 & -0.26 & 0.56 & 0.64 & 0.17 & 0.61 & 0.78 \\
\hline & 41 to 50 & 0.65 & 0.63 & 0.31 & -0.63 & 0.60 & 0.30 & -0.55 & 0.62 & 0.37 & 0.04 & 0.58 & 0.94 & -0.84 & 0.63 & 0.18 \\
\hline \multirow{2}{*}{\multicolumn{2}{|c|}{$\begin{array}{l}\text { Nagelkerke pseudo } r^{2} \\
x^{2} \text { for test for parallel lines }\end{array}$}} & \multicolumn{3}{|c|}{0.54} & \multicolumn{3}{|c|}{0.40} & \multicolumn{3}{|c|}{0.57} & \multicolumn{3}{|c|}{0.54} & \multicolumn{3}{|c|}{0.41} \\
\hline & & \multicolumn{3}{|c|}{$23.19, d f=28, p=0.72$} & \multicolumn{3}{|c|}{ 41.08, $d f=28, p=0.05$} & \multicolumn{3}{|c|}{$18.32, d f=28, p=0.92$} & \multicolumn{3}{|c|}{$20.77, d f=28, p=0.83$} & \multicolumn{3}{|c|}{$34.58, d f=28, p=0.18$} \\
\hline \multicolumn{17}{|c|}{ 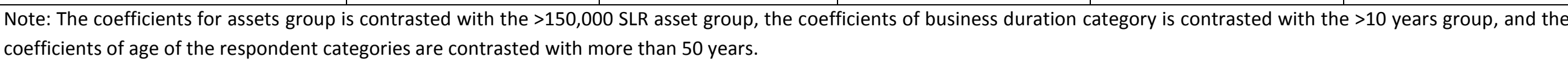 } \\
\hline$* * * \mathrm{p}<0.001$ & $* * p<0.05$ & & $<0.1$ & & & & & & & & & & & & & \\
\hline
\end{tabular}




\section{Interview evidence about the impact of effectuation/causation on deliberate practice}

Using the interview data, we explored these effects in detail to see what they mean in day-to-day terms for micro-entrepreneurs. Of course, not all activities consistent with effectuation or causation can necessarily be linked to deliberate practice: some 'means-based' actions such as selling one's jewellery in order to start a business might only be able to be performed once. So, to ensure our analysis maintained the fundamentally repetitive spirit of deliberate practice, we examined incidents reflecting activities that were logically able to be performed on a repetitive basis. For each element of deliberate practice we consider how it is impacted by specific aspects of effectuation or causation. As before, we identify the specific dimensions of effectuation, causation and deliberate practice.

Having clear performance improvement goals: Table 9 indicates that effectual principles of meansdriven approaches and acknowledging the unexpected have significant effects on having performance improvement goals. That is, both already available knowledge and new knowledge (including knowledge gained from dealing with the unexpected) are used to form business improvement goals. For example, interviewee 24's skills gained when she worked as an insurance agent in a private company led her to develop marketing strategies in her confectionery business, including sales goals (E: Using available means, 'what I know' $\rightarrow$ DP: Performance improvement goals). Similarly, interviewees 8 and 12, although they already knew how to sew, attended training programs to gain new skills, which led them to change the techniques they used to produce their products (E: Using available means 'what I know' $\rightarrow D P$ : Reflection and refinement). The training undertaken by interviewee 12, whose business produces women's dresses, led to her to change how the business operated so that other people, not just the interviewee herself, could finish the garments:

[Earlier] if I cut a piece of cloth for a dress, I needed to sew that [myself]. Everything was in my mind, such as the place of the dart, etc. All the measurements were in my mind too. So, this technique did not work as I had lot of clothes to sew. Then, I attended a class. [...]. After I followed the course, I changed how I worked. Now I draw everything on the materials. So now, anyone can finish them (Interviewee 12, a woman with a dressmaking business).

Similarly, interviewee 24 , who makes sweets, turned an unexpected event into an opportunity and used it to improve the performance of her business.

The first batch I produced, that is, the first batch I made in a large quantity after making 
small quantities, I faced a loss. I do not know whether it was due to the gelatine I used, but most of the jujubes [a sweet] I made started melting. A lot were returned to me. However, I did not get discouraged. I thought 'That is ok, I will sort this out somehow'. I took a sample of the sweets to the person who had trained me at the District Office. [...] I met the officer and he gave me some new ideas. I made a small batch using the new technique and that was successful. Now, I am doing it that way all the time (Interviewee 24, a confectionery business owner).

It is useful to examine this incident in detail. In the first instance, after initial training interviewee 24 experimented with sweet-making on her own at home, but something went wrong when she tried to scale up to commercial production levels. She first knew this when she got feedback from her customer network (her sweets were melting so they were returned to her). So interviewee 24 reassures herself, ("That is okay, I will sort this out somehow), maintaining her motivation even though she did not yet know how to fix the problem. She then used her network again, going back to the person who formally trained her to get advice on how to improve her results. As a result she changed how she made the sweets and produced them successfully. Thus (E: Acknowledging the unexpected $\rightarrow$ DP: Motivation, Performance improvement goals, Feedback, Repetitive practice, Reflection and refinement).

Causation thinking also has significant effects on the deliberate practice dimension of having clear performance improvement goals. As we saw earlier, interviewees regularly set goals, albeit short term ones, and these goals were often related to improving performance (see the quotes from interviewees 20,21, 14, 7, and 9 in sections 5.3 and 5.4). Thus ( $C \rightarrow D P$ : Performance improvement goals). Interviewees 21 and 20, the nursery owners who set goals about increasing plant sales used repeated activities to achieve these goals (see section quotes in 5.4). Thus ( $C \rightarrow D P$ Repetitive practice). Hence, while most micro-entrepreneurs had at least short-term performance goals, not all used repeated activities to reach them.

Motivation: Table 9 shows that effectual logics of means-driven approaches, pre-agreements and alliances, and acknowledging the unexpected have significant effects on the deliberate practice dimension of motivation. Although interviewees did not always use the word motivation, their actions highlight their intentions. As explained above, interviewee 24 was motivated to restore her business production following an unexpected challenge. To cope with it she used available means (i.e., consulted someone she already knew) and experimented. This suggests that effectual thinking and motivation co-occur and reoccur in the business process. The possibility of a pre-agreement which provided a degree of certainty, motivated interviewee 16 to start her business: 
One of my husband's friends said that there was a scheme where you can make garments and return them to the same place, the materials are supplied. So, my husband asked whether I was willing to do that and I said yes, I can do it. Then, my husband contacted the shop, bought two machines under a payment scheme from the same place. [...] I buy materials from there [the shop], which they cut and provide to us. I sew the materials and return them to the same place (E: Pre-agreements $\rightarrow$ DP: Motivation) (Interviewee 16, dress-making business under a forward agreement).

However, the same forward agreement prevents her from hiring a person: the supplier manages risk by shifting losses arising from low sales to her, which in turn reduces her enthusiasm and motivation:

The place I am supplying, sometimes they tell me to delay the supply [of garments] as there are not many sales. That's why I cannot hire anyone. When they ask me to delay supply, I do not get money from there. But, I have to pay a salary to a hired person. I cannot say to that person I cannot pay you until I receive money (Interviewee 16, dress-making business under a forward agreement).

Thus to the extent that the interviewee can create certainty through pre-agreements her motivation is high. When the same pre-agreement actually reduces predictability (paying an employee when she did not have adequate revenues would create unaffordable loss) her motivation is lowered. Accordingly, (E: Pre-agreements/alliances $\rightarrow D P$ : Motivation (high or low)).

Feedback: Table 9 indicates that effectual principles of pre-agreements/alliances and acknowledging the unexpected, and causation thinking significantly influence obtaining and using feedback. Interviewees 3, 8, and 15 explained how having pre-agreements in the form of customer orders led them to expand their customer base and improve production. For example, interviewee 3 supplied her confectionery to nearby shops and when the shop owners said that her snacks were tasty, she gradually increased the quantity and variety of production:

Then, from the first set of shops which I supplied [with confectionery], they said that this is good and tasty, and started buying 20, 10 [packets] more. So, after they said my products were tasty, I added some more ingredients and started expanding ( $E$ : preagreements/alliances, acknowledging the unexpected $+C \rightarrow$ Feedback) (Interviewee 3, a confectionery business owner).

Moreover, when acknowledging the unexpected, micro-entrepreneurs could use experts' feedback 
or experiment on their own, creating feedback for themselves. For example interviewee 24 first experimented on her own with scaling up her confectionery production, failed, met with an expert to get feedback, tried again, and succeeded. Interviewee 22 obtained feedback from an expert when she could not figure out why there was insect damage and disease in her plants:

I had a lot of problems with insect damage [to rose plants]. And I had no idea about the different plant diseases. At such times, I called the person who trained me, explained the symptoms, and asked what to do (E: Acknowledging the unexpected $\rightarrow$ CP: Feedback) (Interviewee 22, a cut-flower business owner).

Causation thinking as reflected in calculating likely revenues and analysing market trends also gave interviewees feedback on their business. For example, when interviewee 24 calculated her returns, she understood what would be the impact of specific changes:

When I calculated the expenses of the materials I used as inputs and compared them with the price of similar products in the market [sweets], I realised that I had made a profit. But, as the amount I produce is quite small, I did not notice that profit. So I decided I had to increase the production. I kept accounts down to the last cent: on the materials I bought, how much I invested, my income. I wrote everything down. I did calculations. Then, I realized if I invested in this, I would not have a loss ( $C \rightarrow D P$ : Feedback) (Interviewee 24, a confectionery business owner).

Similarly, interviewee 19, who studied market trends using catalogues of well-known lingerie brands, identified that she needed two different products for two different customer segments:

[...] I study the market trend. Average people do not spend more than 150 or 200 [SLR] for underwear. For others who have money, both panty and bra need to be made in the same colour ( $C \rightarrow D P$ : Feedback) (Interviewee 19, an owner of a bramaking business).

The logistic regression results showed that micro-entrepreneurs were more likely to be seeking and using feedback during the early years of their business, particularly in the first five years, than when the business was older. This suggests that at start-up micro-entrepreneurs try something based on their available means (i.e., experiment), and change business activities in response to feedback. Thus a lot of entrepreneurial learning appears to occur in the early years of micro-entrepreneurs' businesses. Similarly, when the value of business assets was $<150,000$ SLR, micro-entrepreneurs were more likely to be using feedback, indicating that preferred to learn first and put their business 
on a secure footing before expanding it.

Use of available opportunities to practice: Table 9 shows that all the effectual sub-dimensions and causation are associated with repetitive practice. The interview data provided many examples. For example, interviewees 10, 19, and 24 experimented with their products (i.e., used available means) to ensure the product was satisfactory. If potential losses can be managed, micro-entrepreneurs might then slowly expand production. Interviewee 10 was a case in point:

As an experiment, I made some flowerpots to use in the house. I found I could do that (E: used available means). [...]. At that time, I made one flowerpot a day. While doing household work, when the child was sleeping, I made that. We used those [flowerpots] ourselves at home. Then I started selling to neighbors. I did not think about the price. At that time, I had a 'seettu' [rotating scheme] system (E: Affordable loss) and sold some using that (E: Meansdriven approaches, Affordable loss $\rightarrow$ Repetitive practice) (Interviewee 10, an owner of a cement flowerpot-making business).

Ways of acknowledging - and coping with - the unexpected are also repeatedly practiced. Interviewee 19, the bra-maker, visited potential distributors' shops multiple times, repeatedly pitched her products, was rejected numerous times and maintained her motivation by dealing with the emotional consequences of being rejected. She continued approaching potential distributors before finally forming an initial small pre-agreement:

While supplying to Mavanella [a town], I supplied to Kandy [a town] to a shop named Mega. I went there around 10 times. First, they did not even look at the samples. They said they did not want anything I had. I went a few times more. And more. Sometimes it was very upsetting. There were instances when I even cried. Then, around the tenth time, the manager said, just to see whether there would be any sales, to supply around 24 units. So, I supplied 24 units and came back. Then after around two days they asked me to bring 100 units. Then, after around two weeks, I was asked to bring 200 units. Now at this shop I supply around 1,000 units per month (E: Acknowledging the unexpected $\rightarrow$ DP: Repetitive practice) (Interviewee 19, an owner of a bra-making business).

Similarly, interviewee 23 repeatedly participated in trade fairs and exhibitions where she showcased her products to potential customers, linked up with different stakeholders, and established her customer network. The succession of trade fairs, chance meetings, and follow-up searching has the air of repetitive practice: 
I had an opportunity to participate in a trade fair at Gannoruwa [agriculture department]. During that fair, I met the owner of a traditional medicine store. Now I supply to them. Meanwhile, we found another place to sell the products: a supermarket at Kandy. We deliver around 30-40 bottles per month. [...] This was at another exhibition: 'Kithulaka Waruna [exhibition name]' [shows a photo to the interviewer]. Now, I have another opportunity to supply these products to a buyer in Colombo (E: Acknowledging the unexpected $\rightarrow D P$ : Repetitive Practice $\rightarrow$ ) (Interviewee 23, a Kithul and jaggary business owner).

The quantitative results indicated that causation also significantly influenced the deliberate practice dimension of repetitive practice. As noted earlier, interviewees did not tend to dwell on causation incidents as much as effectuation ones. Nevertheless, interviewee 24, as part of planning her new business location, was practicing a saving routine, by making regular small deposits in the bank.

I do not have enough space here [to expand the business]. I have to move to a new place. After a year, I am planning to make, at least, an advance for some land. [...] I am now depositing $500[S L R]$ every day in the bank $(C \rightarrow$ Repetitive practice) (Interviewee 24, a confectionery business owner).

Reflection and refinement The quantitative analysis indicates that interviewees who could keep potential losses affordable and/or acknowledge the unexpected were well placed to reflect on and refine their strategies. An incident mentioned by interviewee 19 showed how these dimensions of effectuation led her to reflect on and refine a fundamental business practice: where there production was to be done. Dealing with employee theft, which interviewee 19 had not expected when she began employing people to stitch bras, was necessary to prevent unaffordable losses. The remedy lay in diagnosing the problem and then coming up with the remedy: supervising the workers at her own home.

When I first started, I conducted a class at [...] village. I trained some people to stitch bras there. At first I asked them to stitch bras and supply them to me on a self-employed basis. There were around 30 people doing this. After some time, however, I noticed that even though I had supplied enough materials for 100 bras, I was only receiving 90 units back. Doing it that way, I was increasingly losing control of my supply. So then I started having people sew the bras at my home where I could supervise them (E: Affordable loss, Acknowledging the unexpected $\rightarrow D P$ Reflection and refinement) (Interviewee 19, a bra manufacturing business owner).

The duration of the business also significantly impacts reflection on and refinement of business practices: younger businesses aged between two and five years are significantly engaged in changing 
their practices. Table 6 shows that 10 of the 24 interviewees' businesses were less than five years old at the time of interview. While all 24 interviews yielded pointed illustration of how microentrepreneurs became more expert through practice, owners of younger businesses provided recent, highly salient illustrative incidents, and owners of older firms recalled important learning events from when their businesses were younger. Some were powerful enough for the interviewee to conclude that she would remember the incident for the rest of her life.

\section{Discussion}

This systematic, qualitatively-informed review of the quantitative results reveals some important insights about how micro-entrepreneurs become expert entrepreneurs. First, and to answer the first research question, micro-entrepreneurs use both effectual and causal logics during business startup. The interviews showed that micro-entrepreneurs implemented many effectuation principles: they used available resources and their formal and informal knowledge, relied on their family and social network, used inexpensive mechanisms to start a business, obtained short-term orders from customers, and converted challenges into opportunities. On the causation side, they had short-term goals, calculated returns and even analysed their competitors' strategies.

Our second research question asked whether applying effectual and causal principles during start-up facilitated deliberate practice. Our findings confirm this. The ordered logistic regression results indicate that both effectuation and causation are associated with multiple deliberate practice items. For example, two of the four effectuation variables (i.e., means-driven approaches and acknowledging the unexpected) are highly significant predictors (at 95\% significant level) of deliberate practice. In contrast, causation thinking reflects having clear performance improvement goals, feedback, and repetitive practice.

Nevertheless effectuation and causation do not influence deliberate practice to the same extent, or in the same way. As summarized in Table 9, and as illustrated by our qualitative analysis, one, or two, or three of three effectuation principles - means-driven approaches, affordable loss, and preagreements - along with causation, positively influenced specific deliberate practice elements. This suggests that those three effectuation principles and causation have specific affinities or compatibilities with particular aspects of deliberate practice. For example, means-driven approaches and causation both positively influence having performance improvement goals; means-driven approaches and pre-agreements (but not causation) make a difference to micro-entrepreneurs' 
motivation, and so on. Repetitive practice was the only aspect of deliberate practice significantly impacted by all of those three.

The effectuation principle of acknowledging the unexpected, however, presents an important contrast with those three effectuation principles and with causation. Acknowledging the unexpected significantly influences all five aspects of deliberate practice. This finding - considered alongside micro-entrepreneurs' sometimes colourful and poignant accounts of how they had had to acknowledge the expected, cope with it, and sometimes even turn it to advantage - strongly suggests that this principle is at the core of the entrepreneurship experience.

Further, causation promotes entrepreneurial learning differently than effectuation. Causation significantly influences having performance improvement goals, feedback, and repetitive practice, that is, the "venture-building" or "entrepreneuring" aspects. It does not influence the entrepreneur's view of herself or himself as an entrepreneur, i.e., the more personal issues of motivation and reflection/refinement of business practices. By contrast, all elements of effectuation variously touched on these more personal elements. Acknowledging the unexpected influenced both of them - a further indication of the centrality of this dimension to the project of becoming an entrepreneur. Given that the unexpected is virtually by definition prevalent in dynamic business environments, our findings help explain the observation of Keith et al. (2016) and Unger et al. (2009) that deliberate practice is of more help to entrepreneurs when they confront dynamic business environments.

The third research question asked about the impact of the micro-entrepreneurial environment on how effectuation, causation and deliberate practice manifested themselves, including in terms of business changes. We noted both similarities and differences between micro-entrepreneurs and their mainstream counterparts. Just like conventional entrepreneurs, micro-entrepreneurs improved their performance in a self-regulated and unstructured manner. However, specific business tasks were not equally prominent or performed in the same way in the micro-entrepreneurial sphere. In Table 10, using the interview data, we list some common business activities in the formal sector and compare them with how they manifested themselves in our sample. 
Table 10: Comparison of formal sector and micro-entrepreneurs' approaches to practicing business activities

\begin{tabular}{|c|c|c|}
\hline $\begin{array}{l}\text { Common business } \\
\text { activities in formal sector }\end{array}$ & Relevance for HMI clients & How the activity is practiced in the micro-entrepreneurial environment. Micro-entrepreneurs... \\
\hline Business planning* & $\begin{array}{l}\text { Low relevance: Micro- } \\
\text { entrepreneurs tend to } \\
\text { make short term plans. }\end{array}$ & $\begin{array}{l}\text { - Form short-term goals and annual plans } \\
\text { - Gradually increase the quality and quantity of production } \\
\text { - Use feedback from family and immediate social network } \\
\text { - Experiment, reflect and refine, use informal knowledge } \\
\text { - Modify production }\end{array}$ \\
\hline $\begin{array}{l}\text { Forming partnerships/ } \\
\text { alliances }\end{array}$ & $\begin{array}{l}\text { Highly relevance. Micro- } \\
\text { entrepreneurs seek out } \\
\text { pre-agreements and } \\
\text { alliances. }\end{array}$ & $\begin{array}{l}\text { - Identify potential suppliers and customers (through social network or more random } \\
\text { approaches) } \\
\text { - Pitch products by explaining or providing samples } \\
\text { - Approach suppliers and customers, sometimes repeatedly } \\
\text { - Accept rejection and deal with its emotional consequences } \\
\text { - Make formal and informal agreements }\end{array}$ \\
\hline $\begin{array}{l}\text { Negotiating } \\
\text { stakeholder } \\
\text { commitments* }\end{array}$ & $\begin{array}{l}\text { Medium relevance. } \\
\text { Conditions change with the } \\
\text { customer. }\end{array}$ & $\begin{array}{l}\text { - Find out about and accommodate specific stakeholder requirements } \\
\text { - Negotiate conditions } \\
\text { - Modify the product according to stakeholder requirements }\end{array}$ \\
\hline Resource acquisition* & $\begin{array}{l}\text { Medium relevance. Micro- } \\
\text { entrepreneurs use } \\
\text { available, inexpensive } \\
\text { resources, and acquire new } \\
\text { resources gradually. }\end{array}$ & $\begin{array}{l}\text { - Assess available resources (including social network, inexpensive production resources, savings, } \\
\text { etc.) } \\
\text { - Experiment with the means available } \\
\text { - Modify business practices in light of resource constraints } \\
\text { - Re-assess resource requirements, mobilize resources }\end{array}$ \\
\hline Cash management* & $\begin{array}{l}\text { High relevance. Use } \\
\text { multiple formal and } \\
\text { informal arrangements. }\end{array}$ & $\begin{array}{l}\text { - Analyse the short-term cash position } \\
\text { - Calculate current commitments and returns including livelihood and business expenses } \\
\text { - Think of the ways to meet the shortfall (including reciprocal money exchange within social } \\
\text { network, pawning, etc.) } \\
\text { - Limit investments }\end{array}$ \\
\hline
\end{tabular}


Table 10: Comparison of formal sector and micro-entrepreneurs' approaches to practicing business activities

\begin{tabular}{|c|c|c|}
\hline $\begin{array}{l}\text { Common business } \\
\text { activities in formal sector }\end{array}$ & Relevance for HMI clients & How the activity is practiced in the micro-entrepreneurial environment. Micro-entrepreneurs... \\
\hline People management* & $\begin{array}{l}\text { Medium relevance. Mostly } \\
\text { involves managing family } \\
\text { labour. }\end{array}$ & $\begin{array}{l}\text { - } \text { Self-assess personal capacity to perform the activity } \\
\text { - } \quad \text { Assess whether immediate and extended family support can be obtained } \\
\text { - } \quad \text { Arrange business schedules to align with other family members' commitments } \\
\text { - } \quad \text { Assess whether external employees are required and whether their salary is affordable } \\
\text { - } \quad \text { Hire and manage employees depending on seasonal or business needs }\end{array}$ \\
\hline Marketing & $\begin{array}{l}\text { High relevance. Involves } \\
\text { face to face direct } \\
\text { marketing. }\end{array}$ & 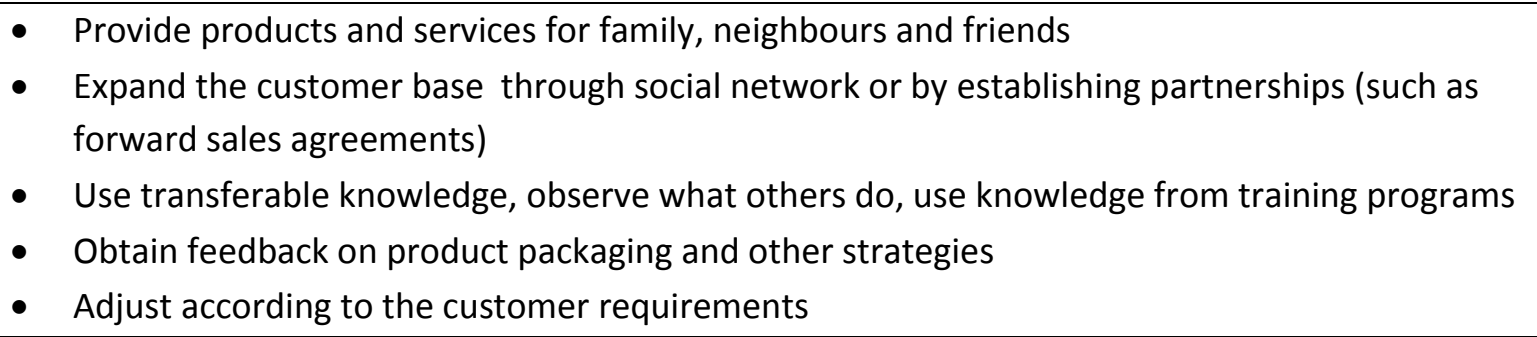 \\
\hline Entrepreneurial learning & $\begin{array}{l}\text { High relevance. Mostly } \\
\text { through training programs } \\
\text { and by meeting experts. }\end{array}$ & $\begin{array}{l}\text { - } \text { Identify knowledge and skill gaps } \\
\text { - } \text { Seek out opportunities to improve knowledge } \\
\text { - } \\
\text { - Attend training programs, meet experts, and obtain/share knowledge/skills from/with peers } \\
\text { - Apply and transfer knowledge to the business }\end{array}$ \\
\hline
\end{tabular}


Table 10 shows similarities and differences between how activities are pursued by 'mainstream', formal sector entrepreneurs and their micro-entrepreneur counterparts, as a result of how business activities and the priority assigned to them are modified in the micro-entrepreneurial environment. Nevertheless micro-entrepreneurs, like other entrepreneurs, identified areas for improvement, adopted performance improvement goals, and made refinements based on experience they gained from the experiments they conducted, feedback they received, and resources they could afford.

Regarding other findings, it is unclear whether they are similar or different between conventional entrepreneurs and micro-entrepreneurs. For example, our study indicates that micro-entrepreneurs' learning through feedback and reflection and refinement of business practices does not happen evenly but rather is concentrated in certain age and size phases. That is, owners of younger businesses of between two and five years of age (not the very youngest, fledgling businesses) and businesses whose asset base is comparatively small $(<150,000 \mathrm{SLR})$ are significantly more engaged in entrepreneurial learning tasks than older businesses with larger asset bases. It appears that the former group have operated long enough to be receiving important feedback about the efficacy of their operations, and their modest asset base makes reflecting on and refining the business a necessity. Further research could investigate whether the learning activities of other entrepreneurial populations are similar or different from those of micro-entrepreneurs.

A further finding which lends itself to further research concerns the central learning task of acknowledging the unexpected, which arises from the intrinsic 'unknown' that all entrepreneurs face. While classifications of uncertainty have already been made, such as the distinction between risk and uncertainty (Knight 1921), our study prompts the question of whether a typology of ways of dealing with uncertainty could be developed. Given that micro-entrepreneurs invoked every form of deliberate practice in order to learn to manage uncertainty, it would be valuable to try to discover which forms of deliberate practice were more effective, and in which circumstances. Such a project, if carried out in more than one type of entrepreneurial population, could bring further contextual clarity to how entrepreneurs manage their central problem. It would, incidentally, be interesting to consider the extent to which a finding drawn from this special, novel group of entrepreneurs could be extrapolated in a different direction to most extensions of entrepreneurial knowledge - from micro-entrepreneurs to mainstream ones rather than in the conventional reverse direction.

Beyond the research questions we began with, our results indicate other ways that how and why effectuation and causation actions enhance entrepreneurial learning among micro-entrepreneurs. 
First, there are conceptual similarities between effectual and causal heuristics and some deliberate practice elements. For example, micro-entrepreneurs' means-driven experimentation resonates with previous research stressing the active nature of entrepreneurial learning. Entrepreneurs - and micro-entrepreneurs too - try things out and, via reflection, learn from success and failure (Mueller \& Shepherd 2016; Kutzhanova et al. 2009), repeat actions that appear most promising, and discard those resulting in failure (Minniti \& Bygrave 2001). Our analysis highlighted that experimentation (trial and error) is virtually synonymous with the deliberate practice elements of obtaining feedback, rehearsal, and reflection/refinement. Acknowledging the unexpected was even more wide-ranging in its effects, leveraging all five elements of deliberate practice. Further, causation-oriented goals and performance improvement goals in deliberate practice are compatible. We also found that some effectual and causal strategies provide a foundation for deliberate practice. For example, preagreements, and family and social networks provide avenues for feedback. Training programs even create networks capable of facilitating mutual peer learning: "acquisition of knowledge and skill through active helping and supporting among status equals or matched companions" (Topping 2005, p. 631). All these conclusions lend themselves to further exploration in, if not immediate extrapolation to, other entrepreneurial populations.

\section{Implications for MFIs}

The findings have implications for MFIs in terms of enhancing their clients' business expertise and learning. For example, MFIs could try to increase micro-entrepreneurs' opportunities for microentrepreneurs to learn from each other's self-regulated and informal practices. MFIs could encourage self-learning and experimentation, provide forums for entrepreneurs to learn from their peers, and encourage micro-entrepreneurs to transfer skills from their previous work to their businesses. Following Banerjee and Duflo's (2011) findings about the value of 'rules of thumb' to entrepreneurs rather than training in complex business procedures, the aim of this must be to simplify business management for micro-entrepreneurs, not make it more difficult. In addition, institutions could provide opportunities for more formal practice, e.g., by providing feedback opportunities, formal sharing of peer insights about improving business performance, and so on. All this would help drive the process of acquiring entrepreneurial expertise. When the MFI did not have expertise in a particular area, it could seek out other sources of information and act as an intermediary between government and non-government institutions and their borrowers.

\section{Limitations}


The above findings need to be interpreted in light of the study's limitations. First, although we used Chandler et al.'s (2011) verified scale, our factor analysis for effectuation did not result in the same statements loading to the same factors as for these authors. This may be an artefact of translation, where 'emic' (i.e., ideas and concepts that are culturally specific) and 'etic' concepts (i.e., ideas and concepts that are general and universal) (Banville et al. 2000) are difficult to separate, or problems with respondents misunderstanding the questions. A possible explanation of the latter problem is that it arose from the comparatively low education levels of participants, or because some items in Chandler et al.'s (2011) scale are less relevant to the microfinance environment than to entrepreneurs of high-tech medical equipment and electrical products. Nevertheless, as mentioned earlier, we were scrupulous about adapting the questionnaire to the microfinance environment without losing the sense of the Chandler et al. (2011) items. Further testing of the scale is needed in any future research among micro-entrepreneurs.

\section{Conclusions}

Our study contributes both theoretically and empirically to understanding of deliberate practice and effectuation/causation thinking. At a theoretical level, our study links effectuation and causation with elements of deliberate practice and shows that effectual/causal approaches enhance microentrepreneurs' expertise acquisition process. While both effectuation and causation link to setting performance improvement goals, feedback, and repetitive practice, effectuation goes beyond the venture-building tasks which these forms of practice develop. Effectuation addresses the entrepreneur's need to learn to deal with uncertainty and, in contrast to causation, taps the personal practice resources needed to do so: motivation and reflection/refinement. We also drew conceptual similarities between specific effectual and causal thinking principles and deliberate practice elements, and illustrated how these lead to further rehearsal of tasks.

At an empirical level we showed that Sri Lankan borrowers who use micro-loans for their business start-up use both effectuation and causation thinking. Our elucidation of contextualized business activities of micro-entrepreneurs - a group not previously studied from an effectuation theory perspective - provide additional evidence about how effectual and causal decision-making manifest themselves in business owners' day-to-day reality, and the specific details of tasks that ultimately can be expected to improve performance.

Further, we linked effectuation and causation with elements of deliberate practice as used by micro- 
entrepreneurs, and pointed out avenues for further research which would show whether these influences and associations work in a similar way in other populations such as conventional, formal sector entrepreneurs. Formal sector entrepreneurs' use of effectuation and causation may affect the elements of deliberate practice differently. Their ways of learning to managing uncertainty may or may not line up in terms of effective with micro-entrepreneurs' approaches. Moreover, depending on each group's previous knowledge and practice, the associations themselves may vary. Future studies could empirically examine the effects of antecedents, and factors potentially mediating or moderating the effects of effectuation and causation on elements of deliberate practice. With ongoing attention to these questions, micro-entrepreneurs - and their mainstream counterparts might not become perfect, but they may well become better.

\section{Acknowledgement}

The authors gratefully acknowledge the reviewers' insightful comments and suggestions, several of which have been incorporated into the paper.

\section{References}

Ahl, H. (2006). Why Research on Women's Enterprise Needs New Directions, Entrepreneurship, Theory and Practice, 30(5), 595-621.

Ahl, H., \& Marlow, S. (2012). Exploring the Dynamics of Gender, Feminism and Entrepreneurship: Advancing Debate to Escape a Dead End, Organization, 19(5), 543-562.

Ahmad, S. Z. (2011). Evidence of the Characteristics of Women Entrepreneurs in the Kingdom of Saudi Arabia: An Empirical Investigation, International Journal of Gender and Entrepreneurship, 3(2), 123-143.

Akpalu, W., Alnaa, S. E., \& Aglobitse, P. B. (2012). Access to microfinance and intra household business decision making: Implication for efficiency of female owned enterprises in Ghana. Journal of Socio-Economics, 41, 513-518.

Aldrich, H. E., \& Martinez, M. A. (2001). Many are called, but few are chosen: An evolutionary perspective for the study of entrepreneurship. Entrepreneurship: Theory and Practice, 25(4), 41-56.

Allet, M. (2015). Mitigating environmental risks in microenterprises. Business \& Society, 56(1), 57-91.

Arend, R. J., Sarooghi, H., \& Burkemper, A. (2015). Effectuation as ineffectual? Applying the 3E theory-assessment framework to a proposed new theory of entrepreneurship. Academy of Management Review, 40(4), 630-651.

Arend, R. J., Sarooghi, H., \& Burkemper, A. C. (2016). Effectuation, not being pragmatic or process theorizing, remains ineffectual: Responding to the commentaries. Academy of Management Review, 41(3), 549-556.

Asian Development Bank (1997). Microenterprise development: Not by credit alone. Viewed 19 November 2015, <http://citeseerx.ist.psu.edu/viewdoc/download;jsessionid=490EADB6946722B6FBE2D5957 56BOEOD?doi=10.1.1.202.4644\&rep=rep1\&type=pdf>.

Ayyagari, M., Beck, T., \& Demirgüç-Kunt, A. (2005). Small and medium enterprises across the globe. viewed 12 May 2017, <http://siteresources.worldbank.org/DEC/Resources/847971114437274304/SME_globe.pdf>. 
Banerjee, A., \& Duflo, E. (2011). Poor Economics: A Radical Rethinking of the Way to Fight Global Poverty. New York: BBS Public Affairs.

Banerjee, A., Duflo, E., Glennerster, R., \& Kinnan, C. (2015). The miracle of microfinance? Evidence from a randomized evaluation. American Economic Journal: Applied Economics, 7(1), 22-53.

Banville, D., Desrosiers, P., \& Genet-Volet, Y. (2000). Translating questionnaires and inventories using a cross-cultural translation technique. Journal of Teaching in Physical Education, 19(3), 374-387.

Baron, R. A. (2016). Self-efficacy and entrepreneurs' adoption of unattainable goals: The restraining effects of self-control. Journal of Business Venturing, 31(1), 55-71.

Baron, R. A., \& Henry, R. A. (2010). How entrepreneurs acquire the capacity to excel: Insights from research on expert performance. Strategic Entrepreneurship Journal, 4(1), 49-65.

Baron, R. A., \& Shane, S. A. (2008). Entrepreneurship: A process perspective. Mason, Ohio: Thomson/South-Western.

Bateman, M. (2010). Why Doesn't Microfinance Work? The Destructive Rise of Local Neoliberalism. Zed Books, London.

Baumeister, R. F., Vohs, K. D., \& Tice, D. M. (2007). The strength model of self-control. Current Directions in Psychological Science, 16(6), 351-355.

Beck, E., Aguilera, M., \& Schintz, J. (2017). Who benefits? The interactional determinants of microfinance's varied effects. Journal of Development Studies [online], 1-21, doi:10.1080/00220388.2017.1296570.

Berends, H., Jelinek, M., Reymen, I., \& Stultiëns, R. (2013). Product innovation processes in small firms: Combining entrepreneurial effectuation and managerial causation. Journal of Product Innovation Management, 31(3), 616-635.

Bernasek, A. (2003). Banking on social change: Grameen Bank lending to women. International Journal of Politics, Culture, and Society, 16(3),369-385.

Bravo, C., Maldonado, S., \& Weber, R. (2013). Granting and managing loans for micro-entrepreneurs: New developments and practical experiences. European Journal of Operational Research, 227, 358-366.

Cahn, M. (2008). Indigenous entrepreneurship, culture and micro-enterprise in the Pacific Islands: Case studies from Samoa. Entrepreneurship \& Regional Development, 20 (1),1-18.

Canadian International Development Agency (2007). Impacts of microfinance initiatives on children: Overview of the study report, viewed 25 April 2017,< http://meda.org/fr/vulnerablepopulations-publications/75-impacts-of-microfinance-initiatives-on-children/file>.

Chandler, G. N., DeTienne, D. R., McKelvie, A., \& Mumford, T. V. (2011). Causation and effectuation processes: A validation study. Journal of Business Venturing, 26(3), 375-390.

Central Bank of Sri Lanka (2015). Annual Report: 2016, viewed 12 May 2017, <http://www.cbsl.gov.lk/pics_n_docs/10_pub/_docs/efr/annual_report/AR2016/English/co ntent.htm>.

Charness, N., Tuffiash, M., Krampe, R., Reingold, E., \& Vasyukova, E. (2005). The role of deliberate practice in chess expertise. Applied Cognitive Psychology, 19(2), 151-165.

Chetty, S., Ojala, A., \& Leppäaho, T. (2015). Effectuation and foreign market entry of entrepreneurial firms. European Journal of Marketing, 49(9-10), 1436-1459.

Corbett, A. C. (2007). Learning asymmetries and the discovery of entrepreneurial opportunities. Journal of Business Venturing, 22(1), 97-118.

Daniel, E. M., Domenico, M. D., \& Sharma, S. (2015). Effectuation and home-based online business entrepreneurs. International Small Business Journal, 33(8), 799-823.

Davidsson, P. (2004). Researching Entrepreneurship. Springer, New York.

Deligianni, I., Voudouris, I., \& Lioukas, S. (2015). Do effectuation processes shape the relationship between product diversification and performance in new ventures? Entrepreneurship: Theory and Practice, 41(3), 349-377. 
De-Mel, S., McKenzie, D. \& Woodfuff, C. (2009). Are women more credit constrained ? Experimental evidence on gender and microenterprise returns, American Economic Journal: Applied Economics, 1(3), 1-32.

De-Mel, S., McKenzie, D. \& Woodruff, C. (2011). Getting credit to high return microentrepreneurs: The results of an information intervention, World Bank Economic Review, 25(3),456-485.

Department of Census and Statistics: Sri Lanka (2014). Labour force survey: Annual report - 2014. viewed 15 May 2017.

<http://www.statistics.gov.lk/samplesurvey/LFS_Annual\%20Report_2014.pdf>.

Department of Census and Statistics: Sri Lanka (2013). Household income and expenditure survey 2012/13, viewed 24 August 2015.

<http://www.statistics.gov.lk/HIES/HIES2012_13FinalReport.pdf>.

De Vaus, D. A. (2014). Surveys in social research. 6th edition. Sydney: Allen \& Unwin.

Dew, N., Read, S., Sarasvathy, S. D., \& Wiltbank, R. (2015). Entrepreneurial expertize and the use of control. Journal of Business Venturing Insights, 4, 30-37.

Dew, N., Read, S., Sarasvathy, S.D., \& Wiltbank, R. (2009). Effectual versus predictive logics in entrepreneurial decision-making: differences between experts and novices. Journal of Business Venturing, 24(4), 287-309.

Dew, N., Sarasathy, S., Read, S., \& Wiltbank, R. (2009). Affordable loss: Behavioral economic aspects of the plunge decision. Strategic Entrepreneurship Journal, 3(2), 105-126.

Downey, R. G., \& King, C. V. (1998). Missing data in Likert ratings: A comparison of replacement methods. Journal of General Psychology, 125(2), 175-191.

Ericsson, A. K. (2006). The Influence of experience and deliberate practice on the development of superior expert performance. In A. K. Ericsson, N. Charness, P. J. Feltovich, \& R. B. Hoffman (Eds.), The Cambridge Handbook of Expertise and Expert Performance (pp. 685-705). Cambridge: Cambridge University Press.

Ericsson, A. K. (2008). Deliberate practice and acquisition of expert performance: A general overview. Academic Emergency Medicine, 15(11), 988-994.

Ericsson, A. K., Krampe, R. T., \& Tesche-Romer, C. (1993). The role of deliberate practice in the acquisition of expert performance. Psychological Review, 100(3), 363-406.

Erogul, M. S., M. Rod, and S. Barragan (2016). 'Contextualizing Arab Female Entrepreneurship in the United Arab Emirates', Culture and Organization [online], 1-15, doi: 10.1080/14759551.2016.1244824.

European Commission (2016). Micro, small and medium-sized enterprises: Definition and scope. viewed 12 May 2017. <http://eur-lex.europa.eu/legal content/EN/TXT/?uri=URISERV\%3An26026>.

Evald, M. R., \& Senderovitz, M. (2013). Exploring internal corporate venturing in SMEs: Effectuation at work in a new context. Journal of Enterprising Culture, 21(3), 275-299.

Fisher, G. (2012). Effectuation, causation, and bricolage: A behavioral comparison of emerging theories in entrepreneurship research. Entrepreneurship: Theory and Practice, 36(5), 10191051.

Fischer, E., \& Reuber, A. R. (2011). Social interaction via new social media: (How) can interactions on Twitter affect effectual thinking and behavior? Journal of Business Venturing, 26(1), 1-18.

Gabrielsson, M., \& Gabrielsson, P. (2013). A dynamic model of growth phases and survival in international business-to-business new ventures: the moderating effect of decision-making logic. Industrial Marketing Management, 42(8), 1357-1373.

Ghorbel, F., \& Boujelbène, Y. (2013). A comprehensive literature review of effectuation theory from 1999 to 2011. International Journal of Entrepreneurial Venturing, 5(2), 168-194.

Gomez, R. \& Santor, E. (2001). Membership has its privileges: The effect of social capital and neighborhood characteristics on the earnings of microfinance borrowers. The Canadian Journal of Economics, 34(4), 943-966. 
GTZ ProMiS (2010). Microfinance industry report: Sri Lanka, viewed 12 June 2013, $<$ http://www.fdc.org.au/data/BWTP_Network__GTZ_Sri_Lanka_Microfinance_Industry_Report_Updated_-_English1.pdf>.

Hodges, N. J., Starkes, J. L., \& MacMahon, C. (2006). Expert performance in sport: A cognitive pespective. In A. K. Ericsson, N. Charness, P. J. Feltovich, \& R. B. Hoffman (Eds.), The Cambridge Handbook of Expertise and Expert Performance (pp. 471-488). Cambridge: Cambridge University Press.

Holcomb, T. R., Ireland, R. D., Holmes Jr, R. M. \& Hitt, M. A. (2009). Architecture of entrepreneurial learning: Exploring the link among heuristics, knowledge, and action. Entrepreneurship: Theory and Practice, 33(1), 167-192.

Hoang, H. \& Antoncic, B. (2003). Network-based research in entrepreneurship: A critical review. Journal of Business Venturing, 18(2), 165-187.

Jütting, J. P., \& de Laiglesia, J. R. (eds) (2009). Is informal normal? Towards more and better jobs in developing countries: An OECD development centre perspective. Viewed 15 April 2017. <http://www.oecd-ilibrary.org/development/is-informal-normal_9789264059245-en>.

Karlan, D., \& Zinman, J. (2011). Microcredit in theory and practice: Using randomized credit scoring for impact evaluation. Science (New York, N.Y.), 332(6035), 1278-1284.

Keith, N., Unger, J. M., Rauch, A., \& Frese, M. (2016). Informal learning and entrepreneurial success: A longitudinal study of deliberate practice among small business owners. Applied Psychology, 65(3), 515-540.

Kevane, M., \& Wydick, B. (2001). Microenterprise lending to female entrepreneurs: Sacrificing economic growth for poverty alleviation. World Development, 29(7), 1225-1236.

Knight, F. H. (1921). Risk, Uncertainty, and Profit. Boston, MA: Hart, Schaffner \& Marx; Houghton Mifflin Company.

Kodithuwakku, S. S. \& Rosa, P. (2002). The entrepreneurial process and economic success in a constrained environment. Journal of Business Venturing, 17(5), 431-465.

Kutzhanova, N., Lyons, T. S. \& Lichtenstein, G. A. (2009). Skill-based development of entrepreneurs and the role of personal and peer group coaching in enterprise development. Economic Development Quarterly, 23(3), 193-210.

Ledgerwood, J., \& Earne, J. (2013). Credit. In J. Ledgerwood, J. Earne \& C. Nelson (eds.), The New Microfinance Handbook: A Financial Market System Perspective, The World Bank, Washington DC, pp. 213-229.

Lingelbach, D., Sriram, V., Mersha, T., \& Saffu, K. (2015). The innovation process in emerging economies: An effectuation perspective. International Journal of Entrepreneurship and Innovation, 16(1), 5-17.

Maine, E., Soh, P-H., \& Dos Santos, N. (2015). The role of entrepreneurial decision-making in opportunity creation and recognition. Technovation, 39-40, 53-72.

Minniti, M. \& Bygrave, W. (2001). A dynamic model of entrepreneurial learning, Entrepreneurship: Theory and Practice, 25(3), 5-16.

Ministry of Finance Sri Lanka (2014). Annual report 2014, viewed 25 May 2017. <http://www.treasury.gov.lk/documents/10181/12870/2014/a9d95930-b101-40dc-9b1bcd1ebb2a82ba?version=1.0>.

Molina-Azorín, J. F., López-Gamero, M. D., Pereira-Moliner, J. \& Pertusa-Ortega, E. M. (2012). Mixed methods studies in entrepreneurship research: Applications and contributions. Entrepreneurship and Regional Development, 24(5/6), 425-456.

Montes Rojas, G. V. \& Siga, L. (2009).On the nature of micro-entrepreneurship: Evidence from Argentina. Applied Economics, 41(21), 2667-2680.

Mueller, B. A., \& Shepherd, D. A. (2016). Making the most of failure experiences: Exploring the relationship between business failure and the identification of business opportunities. Entrepreneurship: Theory and Practice, 40(3), 457-487. 
Neergaard, H., \& Ulhoi, J. P. (2007). Introduction: Methodological variety in entrepreneurship research in H. Neergaard \& J.P. Ulhoi (eds.), Handbook of Qualitative Research Methods in Entrepreneurship, Edward Elgar, Cheltenham, pp. 1-14.

Noice, H., \& Noice, T. (2006). Artistic performance: Acting, ballet, and contemporary dance. In A. K. Ericsson, N. Charness, P. J. Feltovich, \& R. B. Hoffman (Eds.), The Cambridge Handbook of Expertise and Expert Performance (pp. 489-503). Cambridge: Cambridge University Press

Norman, G., Eva, K., Brooks, L., \& Hamstra, S. (2006). Expertise in medicine and surgery. In A. K. Ericsson, N. Charness, P. J. Feltovich, \& R. R. Hoffman (Eds.), The Cambridge Handbook of Expertise and Expert Performance (pp. 339-353). Cambridge: Cambridge University Press.

Nummela, N., Saarenketo, S., Jokela, P., \& Loane, S. (2014). Strategic decision-making of a born global: A comparative study from three small open economies. Management International Review (MIR), 54(4), 527-550.

Omar, A. R. C., \& Ishak, S. (2016). The business behaviours of Malaysian food hawkers. International Business and Management, 12(1), 20-28.

Otoo, M., Lbro, G., Fulton, J. \& Deboer, J.L. (2012). Micro-entrepreneurship in Niger: Factors affecting the success of women street food vendors, Journal of African Business, 13(1), 1628.

Perry, J. T., Chandler, G. N., \& Markova, G. (2012). Entrepreneurial effectuation: A review and suggestions for future research. Entrepreneurship: Theory and Practice, 36(4), 837-861.

Podsakoff, P. M., MacKenzie, S. B., Lee, J. Y. \& Podsakoff, N. P. (2003). Common method biases in behavioral research: A critical review of the literature and recommended remedies, Journal of Applied Psychology, 88(5), 879-903.

Rahman, R., \& Nie, Q. (2011). The synthesis of Grameen Bank microfinance approaches in Bangladesh. International Journal of Economics and Finance, 3(6), 207-218.

Read, S., Dew, N., Sarasvathy, S. D., Song, M., \& Wiltbank, R. (2009). Marketing under uncertainty: the logic of an effectual approach. Journal of Marketing, 73(3), 1-18.

Read, S., \& Sarasvathy, S. D. (2005). Knowing what to do and doing what you know: Effectuation as a form of entrepreneurial expertise. The Journal of Private Equity, 9(1), 45-62.

Reymen, I. M., Andries, P., Berends, H., Mauer, R., Stephan, U., \& van Burg, E. (2015). Understanding dynamics of strategic decision making in venture creation: A process study of effectuation and causation. Strategic Entrepreneurship Journal, 9, 351-379.

Sarasvathy, S. (2001). Causation and effectuation: Toward a theoretical shift from economic inevitability to entrepreneurial contingencies. Academy of Management Review, 26(2), 243263.

Sarasvathy, S. D. (2008). Effectuation: Elements of Entrepreneurial Expertise. Cheltenham: Edward Elgar Publishing Limited.

Shane, S. (2012). Reflections on the 2010 AMR decade awards: Delivering on the promise of entrepreneurship as a field of research. Academy of Management Review, 37(1), 10-20.

Shane, S., \& Venkataraman, S. (2000). The promise of entrepreneurship as a field of research. Academy of Management Review, 25(1), 217-226.

Shaw, J. (2004). Microenterprise occupation and poverty reduction in microfinance programs: Evidence from Sri Lanka. World Development, 32(7), 1247-1264.

Soetanto, D. (2017). Networks and entrepreneurial learning: Coping with difficulties. International Journal of Entrepreneurial Behaviour \& Research, 23(3), 547-565.

Sonnentag, S., \& Kleine, B. M. (2000). Deliberate practice at work: A study with insurance agents. Journal of Occupational and Organizational Psychology, 73(1), 87-102.

Sonnentag, S., Niessen, C., \& Volmmer, J. (2006). Expertise in software design. In A. K. Ericsson, N. Charness, P. J. Feltovich, \& R. R. Hoffman (Eds.), The Cambridge Handbook of Expertise and Expert Performance, (pp. 373-388). Cambridge: Cambridge University Press.

Thapa, A. (2015). Determinants of microenterprise performance in Nepal. Small Business Economics, 45(3), 581-594. 
The World Bank (2006). Microfinance in South Asia: Towards financial inclusion for the poor, viewed 13 June 2013.

http://siteresources.worldbank.org/SOUTHASIAEXT/Resources/Publications/448813$1184080348719 /$ fullreport.pdf.

The World Bank (2015). GDP Per Capita (Current US\$). viewed 24 August 2015. http://data.worldbank.org/indicator/NY.GDP.PCAP.CD.

Topping, K. J.(2005). Trends in peer learning. Educational Psychology, 25(6), 631-645.

Unger, J. M., Keith, N., Hilling, C., Gielnik, M. M., \& Frese, M. (2009). Deliberate practice among South African small business owners: Relationships with education, cognitive ability, knowledge, and success. Journal of Occupational and Organizational Psychology, 82(1), 2144.

Wahid, A. (1999). The Grameen Bank and women in Bangladesh. Challenge, 42(5), 94-101.

Walsh, J. (2014). Business strategies used by micro-SMEs in a Bangkok street market. Journal of Enterprising Communities: People and Places in the Global Economy, 8(2), 147-158.

Werhahn, D., Mauer, R., Flatten, T.C., \& Brettel, M. (2015). Validating effectual orientation as strategic direction in the corporate context. European Management Journal, 33(5), 305-313.

Yadav, V., \& Unni, J. (2016). Women entrepreneurship: Research review and future directions. International Review of Global Entrepreneurship, 6(12), 1-18. Viewed 9 September 2017. https://journal-iger.springeropen.com/track/pdf/10.1186/s40497-016-0055-x?site=journaljger.springeropen.com

Yusuf, J. E., \& Sloan, M. F. (2015). Effectual processes in nonprofit start-ups and social entrepreneurship: An illustrated discussion of a novel decision-making approach. American Review of Public Administration, 45(4), 417-435. 
Annexure 1: Statements used in the deliberate practice scale

\begin{tabular}{ll}
\hline $\begin{array}{l}\text { Deliberate practice elements of } \\
\text { Ericsson (2008) }\end{array}$ & \multicolumn{1}{c}{ Statement used in the study } \\
\hline $\begin{array}{l}\text { Having clear performance } \\
\text { improvement goals }\end{array}$ & $\begin{array}{l}\text { I have a clear goal for each task, whenever I conduct my } \\
\text { day-to-day tasks in the business. }\end{array}$ \\
\hline $\begin{array}{l}\text { Having motivation to improve } \\
\text { performance }\end{array}$ & $\begin{array}{l}\text { I keep myself motivated in my business by learning new } \\
\text { skills, trying new things or thinking about the future. }\end{array}$ \\
& $\begin{array}{l}\text { I feel I do not have anything to improve in my business } \\
\text { (reverse coded). }\end{array}$ \\
\hline Opportunity to obtain feedback & I obtain feedback from others (such as customers, \\
suppliers, employees, government officials, etc.) about \\
different activities in my business. \\
\hline Continuous repetitive practice & $\begin{array}{l}\text { I use all possible opportunities to practice different } \\
\text { business techniques, so as to improve my business. }\end{array}$ \\
\hline Reflection and refinement of & $\begin{array}{l}\text { From time to time, I reflect back and thought about } \\
\text { business tasks }\end{array}$ \\
\hline
\end{tabular}




\section{Annexure 2: Main interview questions ${ }^{2}$}

01 Can you tell me about yourself?

02 Can you tell me the story of your business?

03 Can you explain to me the stage of your business now?

04 When you think back to the beginning of your business:

When did you realise that your idea was a possible basis for a business?

What did you think you needed to start the business?

Did anyone help you when you first started the business? If yes, can you explain who helped you and how?

Can you tell me how you went about producing (or offering) your products or services?

How many did you produce at the beginning?

Did you produce/offer them by yourself? If no, who helped you and how?

What challenges and opportunities have you faced along the way?

05 How has the business changed since you started it?

06 How did you decide how much to borrow from the MFI?

07 Thinking back, when you first started borrowing, were you ever concerned about not being able to repay the loan?

08 When you think back, during loan repayment, what made you keep repaying the loan?

What would have happened if, for some reason, you were not able to pay back the loan?

Would this have been any problem? If yes (or if no), can you explain why?

09 Have you had to think about how to combine your business with other household roles?

10 Apart from the loan, has the microfinance institution had any role to play in your business?

11 Tell me where you think your business is now in relation to your original idea.

\footnotetext{
${ }^{2}$ As these questions were used as part of a wider study, the interview protocol includes questions about other issues.
} 
12 When you think about the different business activities that you have to perform, how well do you think you are doing them?

Do you see any areas to improve?

13 How do you see the future of the business? 